GEOLOGICAL SURVEY CIRCULAR 866

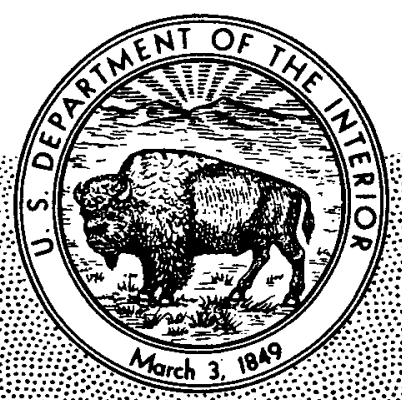

\title{
Geothermal Resources of Southern Idaho
}

MASIER 


\section{DISCLAIMER}

This report was prepared as an account of work sponsored by an agency of the United States Government. Neither the United States Government nor any agency Thereof, nor any of their employees, makes any warranty, express or implied, or assumes any legal liability or responsibility for the accuracy, completeness, or usefulness of any information, apparatus, product, or process disclosed, or represents that its use would not infringe privately owned rights. Reference herein to any specific commercial product, process, or service by trade name, trademark, manufacturer, or otherwise does not necessarily constitute or imply its endorsement, recommendation, or favoring by the United States Government or any agency thereof. The views and opinions of authors expressed herein do not necessarily state or reflect those of the United States Government or any agency thereof. 


\section{DISCLAIMER}

Portions of this document may be illegible in electronic image products. Images are produced from the best available original document. 


\section{Geothermal Resources of Southern Idaho}

By Don R. Mabey
GEOLOGICAL
SURVEY
CIRCULAR
866 
United States Department of the Interior JAMES G. WATT, Secretary

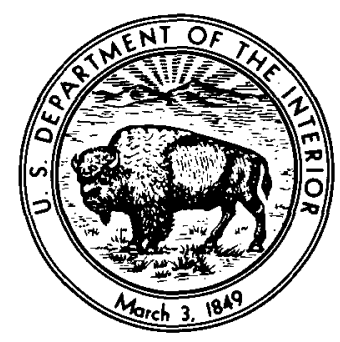

Geological Survey

Dallas L. Peck, Director 


\section{CONTENTS}

Page

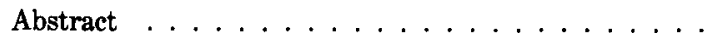

1

Geothermal areas-Continued

Introduction $\ldots \ldots \ldots \ldots \ldots$

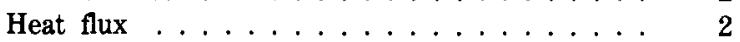

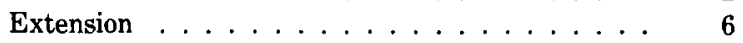

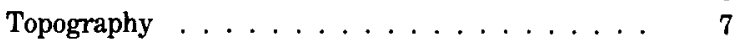

Geothermal systems ............... 8

Hydrothermal convection systems ....... 8

Hot dry rock ....................... 9

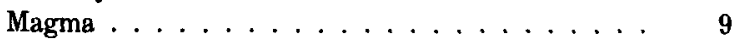

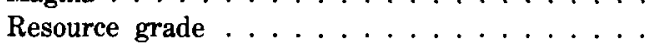

Geothermal areas ...............

Weiser area ................ 9

Idaho batholith ................. 12

Western Snake River Plain . . . . . . . . . . . . 12

Camas Prairie . . . . . . . . . . . . . . . . . 14

Owyhee area ....................... 14

Eastern Snake River Plain ... . . . . . . 15

Island Park area . . . . . . . . . . . . . 18

Lost River area . . . . . . . . . . . . . . . . . 20

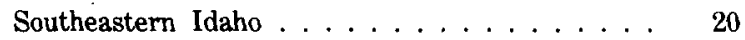

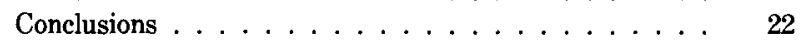

References cited ............... 22

\section{ILLUSTRATIONS}

FIGURE 1. Graph showing thermal energy within $3 \mathrm{~km}$ of the surface in hydrothermal systems with reservoir temperatüres $\geq 90^{\circ} \mathrm{C}$.

2. Map of southern Idaho showing areas dicussed in text, and location of geothermal and volcanic systems. .

3. Map of the western United States showing Idaho, the Cordilleran Thermal Tectonic Anomaly (CTTA), areas of higher than 2.5 heat-flow units, and the Humbolt zone. . . . . . . . . . . . .

4. Map of southern Idaho showing contours on the base of the magnetized crust. . . . . . . . . .

5. Histogram of number of hydrothermal systems with reservoir temperatures $\geq 90^{\circ} \mathrm{C} . \ldots \ldots$

6. Profile across the eastern Snake River Plain through Arco and Blackfoot showing Bouguer Gravity anomaly

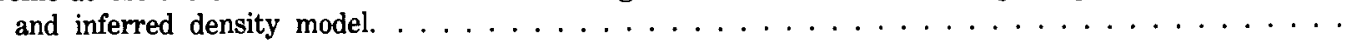

\section{TABLE}

TABLE 1. Geothermal systems in Idaho with calculated reservoir temperatures $\geq 90^{\circ} \mathrm{C}$. 


\title{
Geothermal Resources of Southern Idaho
}

\author{
By Don R. Mabey
}

\begin{abstract}
The geothermal resource of southern Idaho as assessed by the U.S. Geological Survey in 1978 is large. Most of the known hydrothermal systems in southern Idaho have calculated reservoir temperatures of less than $150^{\circ} \mathrm{C}$. Water from many of these systems is valuable for direct heat applications, but is lower than the temperature of interest for commercial generation of electricity at the present time. Most of the known and inferred geothermal resources of southern Idaho underlie the Snake River Plain. However, major uncertainties exist concerning the geology and temperatures beneath the plain. By far the largest hydrothermal system in Idaho is in the Bruneau-Grand View area of the western Snake River Plain with a calculated reservoir temperature of $107^{\circ} \mathrm{C}$ and an energy of $4.5 \times 10^{20}$ joules. No evidence of higher temperature water associated with this system has been found. Although the geology of the eastern Snake River Plain suggests that a large thermal anomaly may underlie this area of the plain, direct evidence of high temperatures has not been found. Large volumes of water at temperatures between $90^{\circ}$ and $150^{\circ} \mathrm{C}$ probably exist along the margins of the Snake River Plain and in local areas north and south of the plain. Areas that appear particularly promising for the occurrence of large high-temperature hydrothermal systems are: the area north of the Snake River Plain and west of the Idaho batholith, the Island Park area, segments of the margins of the eastern Snake River Plain, and the Blackfoot lava field.
\end{abstract}

\section{INTRODUCTION}

The assessment of the geothermal resources of the United States completed by the U.S. Geological Survey in 1978 (Muffler, 1979) indicates that the geothermal resource in southern Idaho (south of $46^{\circ} \mathrm{N}$. lat) is large. The evaluated igneous systems in southern Idaho contain 40 percent of the energy in such systems outside of National Parks. This percentage is more than that of the second and third states, California and Alaska, combined. The 36 known hydrothermal convection systems in southern Idaho with reservoir temperatures $\geq 90^{\circ} \mathrm{C}$ contain 32 percent of the total energy in such systems in the United States outside of $\mathrm{Na}$ - tional Parks (fig. 1). This percentage is second only to that of California. The energy estimated for undiscovered hydrothermal convection systems in Idaho is 34 percent of the United States totalthe largest of any state. The total estimated energy in discovered and undiscovered hydrothermal convection systems in Idaho $\geq 90^{\circ} \mathrm{C}$ is greater than that of any other state. The Idaho resource in systems $\geq 150^{\circ} \mathrm{C}$ is less impressive. Most of the known resources in Idaho are lower than $150^{\circ} \mathrm{C}$ and much of it is in one large system, BruneauGrand View, with a calculated reservoir temperature of $107^{\circ} \mathrm{C}$. In addition to the resource $\geq 90^{\circ} \mathrm{C}$, water in the temperature range from $30^{\circ}$ to $90^{\circ} \mathrm{C}$ underlies large areas of southern Idaho.

Although the geothermal resource in southern Idaho is large, the only commercial development has been for space heating, fish farming, and bathing. Only one of the systems, Raft River, has been investigated in detail. Considerable uncertainty exists concerning the distribution and size of the resource. In 1977, the U.S. Geological Survey, the U.S. Department of Energy, The Idaho Department of Water Resources, and the U.S. Forest Service began a coordinated study of the geothermal resources of southern Idaho designed to develop a better understanding of the resource. This program has involved geological, geophysical, hydrological, and geochemical studies supported by drilling. Numerous investigators from the four agencies and from several universities and commercial organizations have been involved in the work. Some of the studies have been completed and others are continuing. This report does not attempt to synthesize the results of all the studies but rather present conclusions as to what the studies indicate about the geothermal resources of southern Idaho at temperatures $\geq 90^{\circ} \mathrm{C}$. The Idaho Department of Water Resources has the primary 


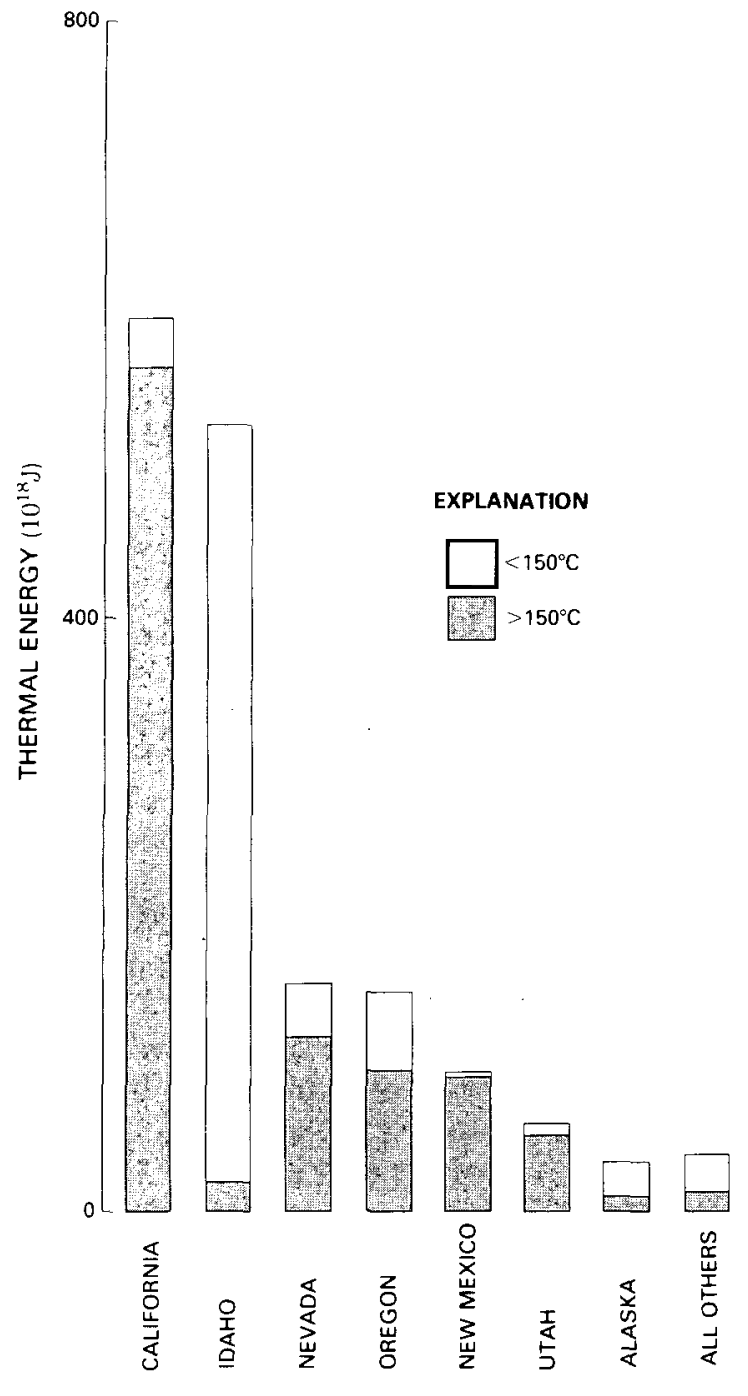

Figure 1.-Thermal energy (in $10^{18}$ joules) within $3 \mathrm{~km}$ of the surface in hydrothermal systems with reservoir temperatures of $\geq 90^{\circ} \mathrm{C}$. Data from Brooks and others (1979).

responsibility for the investigation of the low-temperature resources (lower than $90^{\circ} \mathrm{C}$ ) and a report on their work has been published (Mitchell and others, 1980).

All the known geothermal resources in Idaho at temperatures $\geq 90^{\circ} \mathrm{C}$ are south of $46^{\circ} \mathrm{N}$. lat and most are in an arc $100 \mathrm{~km}$ wide that extends across the state from Yellowstone National Park to the Weiser area and that includes the Snake River Plain (fig. 2). The Snake River Plain, which is a topographic depression completely covered with Cenozoic sedimentary and volcanic rocks, contains most of the energy in identified geothermal sys- tems and most of the postulated undiscovered resource in the state. Although significant geothermal systems occur outside the Snake River Plain, their energy content is small compared with the resource in or immediately adjacent to the plain.

\section{REGIONAL FEATURES}

All of southern Idaho lies within the Cordillerian Thermotectonic Anomaly (CTTA) (fig. 3) as defined by Eaton and others (1976). The CTTA, which contains 70 percent of the identified hydrothermal convection systems with estimated reservoir temperatures $\geq 90^{\circ} \mathrm{C}$ in the conterminous United States, is centered near the southwest corner of Idaho. The CTTA was defined on the basis of several characteristics. Primarily they were: (1) High heat flux indicated by heat-flow measurements, thermal springs and volcanism; (2) rapid crustal spreading indicated by extensional faults and earthquakes with fault-plane solutions indicating extension; and (3) by the generally high surface elevation. These three criteria, supplemented by additional geological and geophysical considerations, can be used to examine the regional geological and geophysical features of southern Idaho as indicators of the geothermal resources in the region.

\section{HEAT FLUX}

Hydrologic disturbances over much of southern Idaho limit the usefulness of heat-flow measurements obtained in shallow holes, and the regional heat-flow patterns are not well defined. Brott and others $(1976,1978)$ and Brott and others (1981) have made numerous heat-flow measurements in southern Idaho, and Blackwell (1978) used the earlier data to conclude that a large heat-flow high underlies much of southern Idaho but that the heat flow in the Idaho batholith is lower and near the normal for the area of the CTTA. Brott and others (1981) suggest a model in which a large heat source is emplaced under the Snake River Plain beginning about 20 million years ago in the west and moving eastward in time toward Yellowstone National Park. High heat-flow values near the margins of the western Snake River Plain and lower values on the plain are attributed by them to a combination of thermal refraction caused by Cenozoic rocks with low thermal conductivity underlying the plain and low heat generation in 


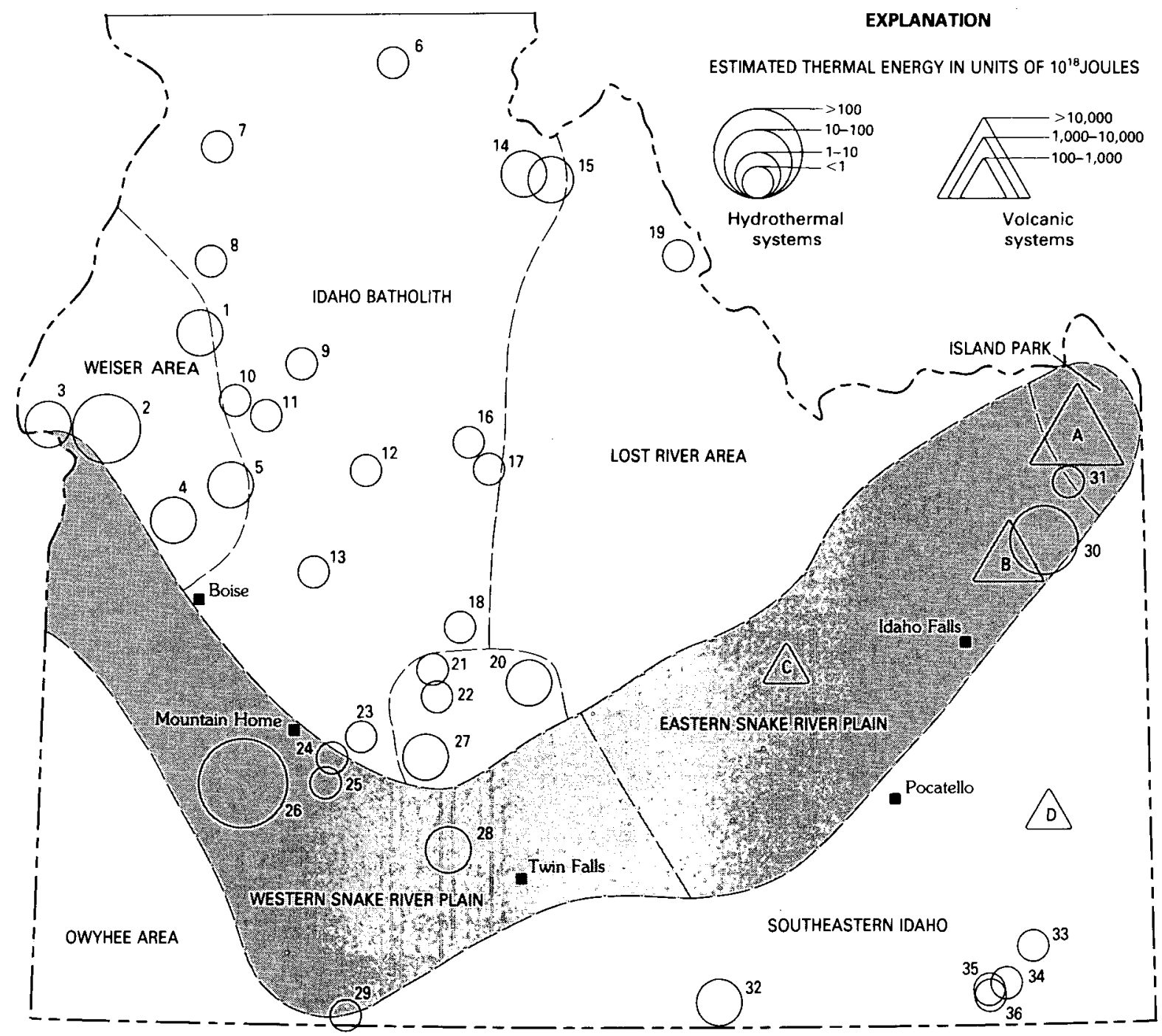

Figure 2.-Map of southern Idaho showing named areas (bounded by dashed lines) discussed in text, location of geothermal systems with number designations referenced to table 1, and volcanic systems with letter designations referenced to text.

the crust under the plain. The low heat flow under the eastern Snake River Plain is attributed to the movement of ground water in volcanic aquifers.

Some physical properties of rocks are temperature-dependent, and measurements of these physical properties by geophysical techniques provide an indication of temperature at depth. By far the most important mineral in determining the magnetism of rocks is magnetite. The Curie temperature of magnetite is about $580^{\circ} \mathrm{C}$; therefore, large magnetic anomalies are not likely to be produced by rocks much higher than this temperature. The magnetic anomalies over southern Idaho have been analyzed to determine the elevation of the base of the magnetized crust, which is assumed to coincide with the Curie isotherm surface and indicate temperature distributions deep in the crust (Bhattacharyya and Mabey, 1980). Extremely high electrical conductivity also may indicate high temperature. Magnetotelluric soundings have been used in southern Idaho to map a highly conductive layer in the crust, and variations in the depth to this layer may provide an indication of major thermal anomalies (Stanley and others, 1977). Deeper conductivities have been determined in the area of the eastern Snake River Plain using measurements of geomagnetic induction. The analysis of teleseismic $P$-wave delays recorded 


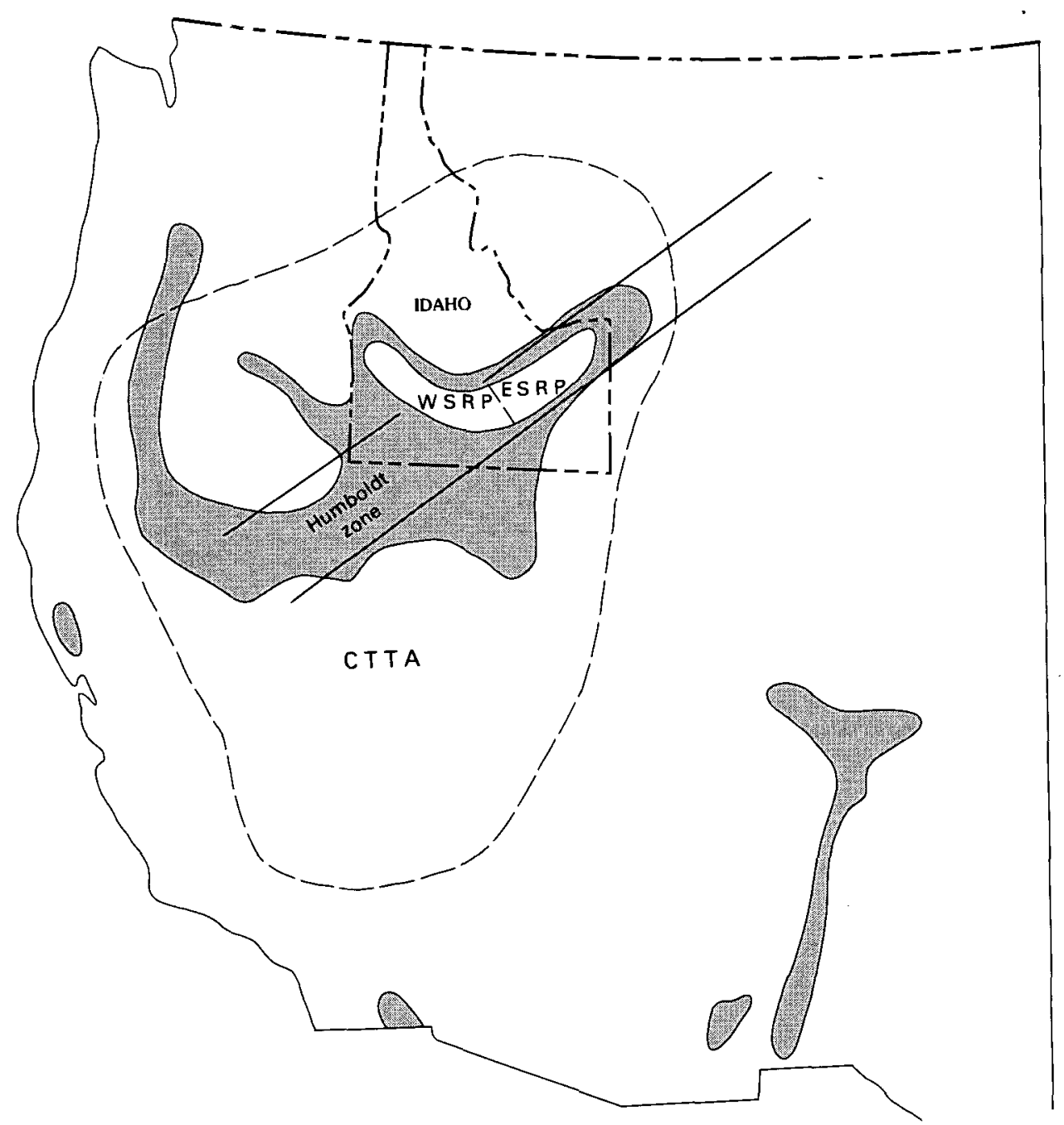

FIgURE 3.-Map of the western United States showing Idaho, the Cordilleran Thermal Tectonic Anomaly (CTTA; from Eaton and others, 1976), areas (stippled) of higher than 2.5 heat-flow units (HFU; from Blackwell, 1978), and the Humboldt zone (from Mabey and others, 1978). WSRP, western Snake River Plain; ESRP, eastern Snake River Plain.

in southeastern Idaho define a low-velocity zone that may indicate a large, deep thermal anomaly. Information from all these techniques has been used in an attempt to define regional thermal anomalies in southern Idaho.

A map of the elevation of the base of the magnetized crust is shown in figure 4. This map is based on the work of the late B. K. Bhattacharyya and is modified from figure 8 of Bhattacharyya and Mabey (1980). It differs from the early version in that some determinations considered less reliable (B. K. Bhattacharyya, written commun., 1979) have been rejected. Little correlation is apparent between the computed elevation of the base of the magnetized crust and the Snake River Plain. This lack of correlation suggests that the Snake River Plain is not related to a simple thermal event. The thickness of the magnetized crust thins northeastward toward Yellowstone National Park where previous analysis indicated a thickness of $5-6 \mathrm{~km}$ (Bhattacharyya and Leu, 1975). A high in the base of the magnetized crust coincides with The Craters of the Moon, an area of young basalt flows, and with a series of young rhyolite domes on the eastern Snake River Plain (CM, fig. 4). Another high is coincident with the Albion Mountains (AM, fig. 4), where Precambrian metamorphic rocks crop out. The Raft River geothermal system is in the area of this high. The contouring suggests a connection between the high in the Albion Moun- 


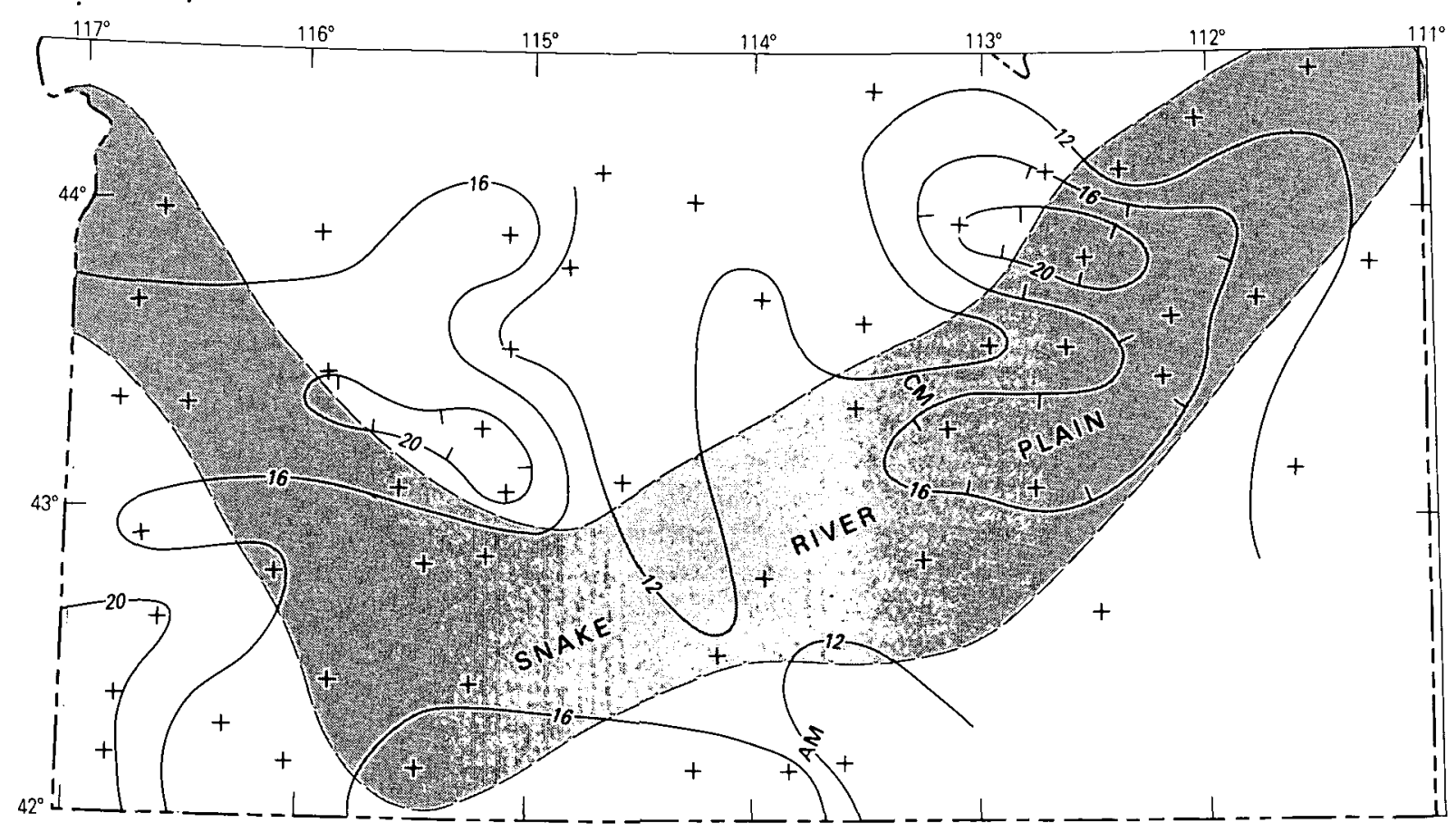

FIGURE 4.-Map of southern Idaho showing contours on the base of the magnetized crust (modified from Bhattacharyya and Mabey, 1980). Contours are kilometers below sea level based on elevations determined at points marked by plus signs. CM, Craters of the Moon; AM, Albion Mountains.

tains area and a high north of the plain over the eastern edge of the Idaho batholith and the area to the east. Intermediate elevations were determined over most of the western Snake River Plain.

Magnetotelluric soundings in southeastern Idaho have been interpreted to indicate a highly conductive zone in the crust at elevations ranging from 9 to $25 \mathrm{~km}$ below sea level (Stanley and others, 1977). The conductive layer is nearest the surface in the area of the Albion Mountains and deepest along the axis of the eastern Snake River Plain. W. D. Stanley (oral commun., 1979) reported that the conductive layer generally appears to be nearer the surface along the margins of the eastern Snake River Plain than along the axis. Stanley and others (1977) believed that the conductive zone is related to high temperatures. Good agreement exists between the elevation of the magnetized crust as determined by Bhattacharyya and the elevation of the conductive layer in the crust determined by magnetotelluric sounding in southeastern Idaho (Bhattacharyya and Mabey, 1980, fig. 9). Preliminary results from the geomagnetic induction surveys over the eastern
Snake River Plain do not indicate a deep conductivity anomaly coincident with the plain (Fitterman, 1979; and Wier, 1979).

The intermountain seismic belt extends into eastern Idaho from the north and south but does not extend onto the eastern Snake River Plain, where few earthquakes occur (Smith, 1978). The low number of earthquakes on the eastern Snake River Plain may indicate that the temperature in the crust under this part of the plain is so high that the strain is accommodated without fracturing. Evans and Iyer (1979) and J. R. Evans (written commun., 1981) have interpreted the delay in teleseismic $P$-waves in the eastern Snake River Plain as indicating a low velocity body $100 \mathrm{~km}$ wide and extending from 100 to $250 \mathrm{~km}$ below the surface. They concluded that this body increases in size but decreases in velocity contrast to the southwest. The seismic data appear to suggest a thermal anomaly under the northeastern side of the Snake River Plain that is not apparent in the resistivity data.

Volcanic rocks of Neogene and Quaternary age occur over all the Snake River Plain, much of the area southwest of the plain, west of the Idaho 
batholith, and locally southeast of the Snake River Plain. In the east, these rocks overlap the north edge of the plain but are not known to extend far north of the plain. The volcanic rocks are predominantly basalt and rhyolite with basalt being the most common youngest and oldest rock and rhyolite the most abundant intermediate-age rock. In general, the rhyolite is progressively younger toward the east (Armstrong and others, 1975; Christiansen and McKee, 1978) but young basalt flows are widespread over the plain. The beginning of the Neogene volcanic activity appears to coincide with the start of large-scale extension of the northern Basin and Range province. Although the fundamental structure of the Snake River Plain and the relationship between the plain and the widespread Neogene and Quaternary volcanism in the region are still debated, the origin of the plain and the volcanism probably are both related to the development of the CTTA and extension of the northern Basin and Range province.

\section{EXTENSION}

Lachenbruch and Sass (1978) have developed a model of an extending lithosphere and related heat flow for the Basin and Range province. The model assumes that heat is supplied to the extending lithosphere by the intrusion of basalt dikes or by the underplating of basalt on the lithosphere. The model indicates that an increase of $40 \mathrm{~mW} / \mathrm{m}^{2}$ (milliwatts per square meter) in heat flow could be produced by 1-2 percent extension per million years. Thus, an understanding of the nature and age of the extensional tectonics of southern Idaho is important in the evaluation of the geothermal resources.

Although generally east-west extension characterizes most of the CTTA, the orientation and effect on the upper crust of the extension varies with time and location. South of Idaho, a symmetry to the extension is apparent with the axis of symmetry near the north-south axis of the CTTA (Eaton and others, 1978). In southern Idaho, the symmetry of the extension is not nearly so pronounced.

Beginning about 17 million years ago, large volumes of basalt were erupted in the Columbia Plateau and in eastern Oregon and western Idaho at about the same time that regional extension appears to have begun in the northern Basin and
Range province and perhaps throughout the entire area of the CTTA. The crust in the region probably was relatively competent at the beginning of the extensional tectonics, and rifts developed with basalt rising to the surface and accumulating in subsided areas that developed on the surface. The Cortez or Nevada rift in north-central Nevada was one of these rifts (Zoback and Thompson, 1978; Mabey and others, 1978), and the western Snake River Plain may have been the site of another. Christiansen and McKee (1978) suggested that these two features originated as a continuous rift that was subsequently offset by transform displacement along the northern boundary of the Great Basin. The Cortez rift is well exposed, but most of the evidence for a rift under the western Snake River Plain is deeply buried under younger sedimentary and volcanic rock. The primary data relating to the structure of the western Snake River Plain are: (1) normal faults (plain side down) near the margins of the plain and a regional dip of the Cenozoic rocks toward the axis of the plain, (2) the seismic refraction data indicating a thinning of the upper crust and a thickening of the lower crust under the plain, (3) a large gravity high cresting near the axis of the plain, (4) a magnetic anomaly consisting of a high along the southern edge of the plain and a low along the north edge, and (5) a few deep drill holes.

These data can be interpreted in several ways. Mabey (1976) presented an interpretation that infers that the crest of the gravity high overlies the thinnest upper crust and that the entire western plain is a deep subsidence containing a dense magnetic mass that is probably Miocene basalt similar to that cropping out north of the western end of the plain. After this interpretation was published, a correlation between an appendage of the magnetic high over the western Snake River Plain and an outcrop of Eocene volcanic rocks southwest of the plain was noted. This correlation suggests that Eocene volcanic rocks as well as Miocene basalt may underlie the plain. The data from deep drill holes west of Boise (Bowen and Blackwell, 1975) appear consistent with the interpretation that a large mass of dense and highly magnetized volcanic rock underlies the plain, but the data from a deep hole near Grand View do not support this interpretation. The latter hole is reported to have bottomed in granite without having penetrated any great thicknesses of basalt or other dense, 
highly magnetized rocks that would produce the measured magnetic and gravity anomalies (McIntyre, 1979). The source of the magnetic anomaly and most likely part of the gravity anomaly must underlie the area of the hole. Perhaps the granitic body is thin, being part of a sill or a large slide block from much higher areas of granite a few kilometers to the southwest. Gravity data indicate that the western Snake River Plain is underlain by a large positive mass anomaly and that the plain is in approximate isostatic equilibrium with the adjoining highlands. The most recent subsidence of the plain may relate primarily to isostatic adjustment and may not reflect major extension of the crust.

As the temperature of the crust in the CTTA increased, the style of the extensional deformation changed. No more major rifts developed and the direction of extension rotated clockwise (Zoback and Thompson, 1978). In late Miocene and Pliocene time, large volumes of silicic volcanic rocks were erupted in southeastern Idaho, and the center of this activity migrated northeast along the current location of the Snake River Plain. In southeastern Idaho, extensive basins developed and filled with great thicknesses of sedimentary and volcanic rock of the Miocene and Pliocene Salt Lake Formation. These basins, which may have extended onto the area of the present eastern Snake River Plain, have not been studied in detail but they appear to have been considerably broader than the present topographic basins north and south of the eastern Snake River Plain.

The boundary between the eastern and western Snake River Plain used in this report is based on a marked contrast of gravity and magnetic anomalies. The subsurface geology of the eastern Snake River Plain is largely speculative with only one deep drill hole for control and the geophysical and geological data subject to conflicting interpretations. Almost certainly the eastern plain is, at least in part, an extensional feature with a complex of calderas underlying the northeastern end of the plain. A major regional magnetic lineament (Eaton and others, 1975; Mabey, Zietz, and others, 1978) has been interpreted as indicating that the location of the eastern Snake River Plain is controlled by an old crustal feature (The Humboldt zone, fig. 3). Christiansen and McKee (1978) proposed that the eastern Snake River Plain is part of the northern transform boundary of the
Great Basin and that shear melting at the base of the crust developed into a self-sustaining melting anomaly. Brott and others (1981) suggest that the entire Snake River Plain represents the track of a moving thermal source now under Yellowstone National Park.

When the eastern Snake River Plain began to develop as a major depression has not been determined. Subsidence likely occurred in the area at the beginning of regional extension about 17 million years ago. Whether this took the form of a single elongate depression or a group of smaller basins is not clear. In Mabey (1978a) the long wave length gravity anomalies are intepreted as reflecting a series of the early basins, but the evidence for these is not compelling. Most of the large Basin and Range structures south of the eastern Snake River Plain do not extend to the edge of the plain, and the geophysical data suggest that similar structures north of the plain do not extend far onto the plain. The major Basin and Range faults, which have been active in late Cenozoic time, are likely to be predominantly listric faults that flatten at depth and merge with the underlying thrust faults. The extension of the crust in eastern Idaho in late Cenozoic time appears in part to involve some of the same fault surfaces that formed during the shortening of the crust in late Mesozoic time. We do not know if the thrust faults underlie the eastern Snake River Plain.

\section{TOPOGRAPHY}

Although all of southern Idaho lies within the regional topographic high associated with CTTA, the dominant topographic feature of southern Idaho is the Snake River Plain with low surface relief and an elevation that is generally about 500 $\mathrm{m}$ below the average elevation of the adjoining highlands. The northwest end of the Snake River Plain, which is less than $1 \mathrm{~km}$ above sea level, is the lowest large area within the CTTA. Toward the east, the elevation of the plain rises as does the average elevation of the adjoining highlands. Brott and others (1981) relate the eastward increase in the elevation of the Snake River Plain to increasing temperature of the crust and resulting thermal expansion. Gravity studies indicate that the plain is in approximate isostatic equilibrium with the adjoining highlands but that most of eastern Idaho is undercompensated and stands 
at a higher regional elevation than can be explained by isostasy (Mabey, 1978a). Basin and Range topography is prominent in eastern Idaho outside the Snake River Plain. The development of the topography of southern Idaho was closely related to the development of some of the geothermal systems.

\section{GEOTHERMAL SYSTEMS}

\section{HYDROTHERMAL CONVENTION SYSTEMS}

The geothermal resources in southern Idaho that are of most immediate economic interest are hydrothermal convection systems. Hot water can be produced from these systems and the energy extracted from the water. Most of the known hydrothermal convection systems in Idaho have been identified because water from the system is being discharged at the surface in a spring or was encountered in drilling a water well or oil and gas exploration well. Thermal water in springs and shallow wells is usually part of a hydrothermal convection system that may contain large volumes of water at depth with a higher temperature than the near-surface water. The hot water discharged from springs can be used in applications where small volumes of relatively low-temperature water are required such as small-scale space heating. But in applications that require either large volumes of water or high-temperature water, for example the generation of electricity, the deeper parts of the system must be tapped.

The major elements of a hydrothermal convection system are: (1) conductive heat flow supplying heat to the systems; (2) cold water descending through a permeable zone, such as fratured rock, to a zone of high temperatures where the water is heated by direct contact with hot rock; (3) the hot water being less dense ascending toward the surface in a porous zone; (4) a reservoir of porous rocks where hot water is stored and where the reservoir rock is heated; and (5) some systems discharge hot water into shallow aquifers or at the surface in springs. The system is continually transporting heat toward the surface, but the primary resource is the heat that is stored in the water and rock of the reservoir. Development of the resource normally will be by drilling wells into the reservoir and extracting the hot water from the reservoir. Some heat will be supplied to the reservoir by convection in the system during the period of production, but the rate of resupply will usually be small compared to the rate of production and the reservoir will be depleted. Although the reservoir may eventually recover, the time required normally will be too great to be of interest in a resource study. Therefore, the resource of primary interest is the recoverable energy in the reservoir.

Although considerable uncertainty exists about what the representative deep thermal gradients are for southern Idaho, some conclusions can be drawn from existing data. Thermal gradients of $31^{\circ}$ and $47^{\circ} \mathrm{C} / \mathrm{km}$ were measured in holes in granite southwest of the Snake River Plain (Urban and Diment, 1975). Brott and others (1978) reported gradients of $40^{\circ}$ to $100^{\circ} \mathrm{C} / \mathrm{km}$ in numerous areas of southern Idaho, but their highest values probably reflect near-surface rocks with low thermal conductivity and the presence of hydrothermal convection systems. Lachenbruch and Sass (1978) indicated that thermal gradients of from $25^{\circ}$ to $50^{\circ} \mathrm{C} / \mathrm{km}$ are representative of the northern Basin and Range province where surface heat flow ranges from 55 to $125 \mathrm{~mW} / \mathrm{m}^{2}$. The normal gradients over most of southern Idaho probably fall in the $25^{\circ}$ to $50^{\circ} \mathrm{C} / \mathrm{km}$ range. Possible support for this conclusion is provided by the Curie isotherm depths suggested by the magnetic anomalies that indicate that a temperature of about $550^{\circ} \mathrm{C}$ occurs at 10 to $23 \mathrm{~km}$ below the surface over most of southern Idaho. The maximum calculated reservoir temperatures for any known system in Idaho is $171^{\circ} \mathrm{C}$ (Brook and others, 1979), and this could be obtained by water circulating to depths of about $6 \mathrm{~km}$ in low-gradient areas and $3 \mathrm{~km}$ in highgradient areas. The depths could be substantially less in areas underlain by great thickness of rocks with low thermal conductivity. Thus, the temperatures calculated for all known geothermal systems in southern Idaho could be obtained by water circulating to moderate depths in the geothermal gradients that are estimated to be normal for the region. Any local heat sources that may exist will enhance the thermal gradients and reduce the depth of circulation required to obtain a given temperature.

Some hydrothermal reservoirs develop without important convection with water in a confined aquifer heated by the conductive heat flow. This kind of reservoir will not contain water at as high 
temperature at a given depth as will the reservoir in a convection system.

\section{HOT DRY ROCK}

Large amounts of thermal energy are contained in hot rock that, because of low permeability, does not contain significant amounts of extractable water. These reservoirs are often referred to as "hot dry rock" although the rock is probably never completely dry and some reservoirs may contain substantial amounts of water. Research directed toward the development of technology to extract the heat from these reservoirs by circulating a fluid through the rock is in progress. Hot impermeable rock is known to exist in several areas of Idaho at depths of less than $3 \mathrm{~km}$, and at great depths the energy content of these rocks must be considerable. However, until the technology and economics of extracting energy from these hot impermeable rocks is demonstrated, they cannot be termed a resource.

\section{MAGMA}

A third type of geothermal reservoir is molten or partially molten rock. Great amounts of heat are transported toward the surface of the earth as magma moves upward to form plutons or to be extruded at the surface as lavas or ash flow tuffs. Bodies of molten magma, both basalt and rhyolite, may exist within the crust in several areas of southern Idaho. However, the technical problems of extracting heat from these reservoirs are formidable and commercial development is not likely to occur for many years, if ever.

\section{RESOURCE GRADE}

Although the geothermal resource of southern. Idaho is large, most of the energy is in hydrothermal convection systems with estimated temperatures less than $150^{\circ} \mathrm{C}$. Figure 5 illustrates the reservoir temperature of the southern Idaho systems as well as those of adjacent states and all those in the conterminous United States. Note the absence of any extremely high temperatures for the Idaho system. Most of the temperatures are based on geochemical thermometry of water from springs and shallow wells. The computed temperatures assume that the thermal waters have not mixed with cold water unless mixing could be proved and quantitatively evaluated; this was rarely possible with data available (Brook and others, 1979). The average precipitation in Idaho is relatively high-more than twice that of Nevada and western Utah. In many of the geothermal areas of Idaho there is a shallow ground water that is probably mixing with the thermal water leaking from the underlying geothermal reservoirs. Geochemical temperatures determined for these mixed waters generally will be lower than the actual reservoir temperatures. Additional work will likely result in an increase of the calculated reservoir temperatures of some of the Idaho systems.

\section{GEOTHERMAL AREAS}

The geology of Idaho is varied and complex and the characteristics of the geothermal systems that occur throughout the southern part of the State are determined by the local and regional geology. Southern Idaho is here divided into nine areas on the basis of the regional geology and the character of the geothermal systems (fig. 2). The geothermal systems with reservoir temperatures $\geq 90^{\circ} \mathrm{C}$ are listed in table 1 as are estimated mean reservoir temperature, volume, and energy. The data for this table are from Brook and others (1979). Additional data on most of the systems are available in Young and Mitchell (1973). Plate 1 of Mitchell and others (1980) is a $1: 500,000$ scale map that shows the location of these systems as well as data on the systems with reservoir temperatures $\leq 90^{\circ} \mathrm{C}$.

\section{WEISER AREA}

Five geothermal systems with estimated reservoir temperatures higher than $130^{\circ} \mathrm{C}$ are in one area north and northwest of Boise, here called the Weiser area (fig. 2). This area includes the extreme northwest end of the western Snake River Plain, a strip along the west edge of the Cretaceous Idaho batholith, and an area north of the plain underlain by basalt and sedimentary rock of Miocene age. The Weiser area is adjacent to the Vale geothermal area in eastern Oregon where reservoir temperatures of $127^{\circ} \mathrm{C}, 157^{\circ} \mathrm{C}$, and $188^{\circ} \mathrm{C}$ are estimated for three systems. Heat flow and thermal gradients over most of the area appear to be high. Although the systems in the Weiser 

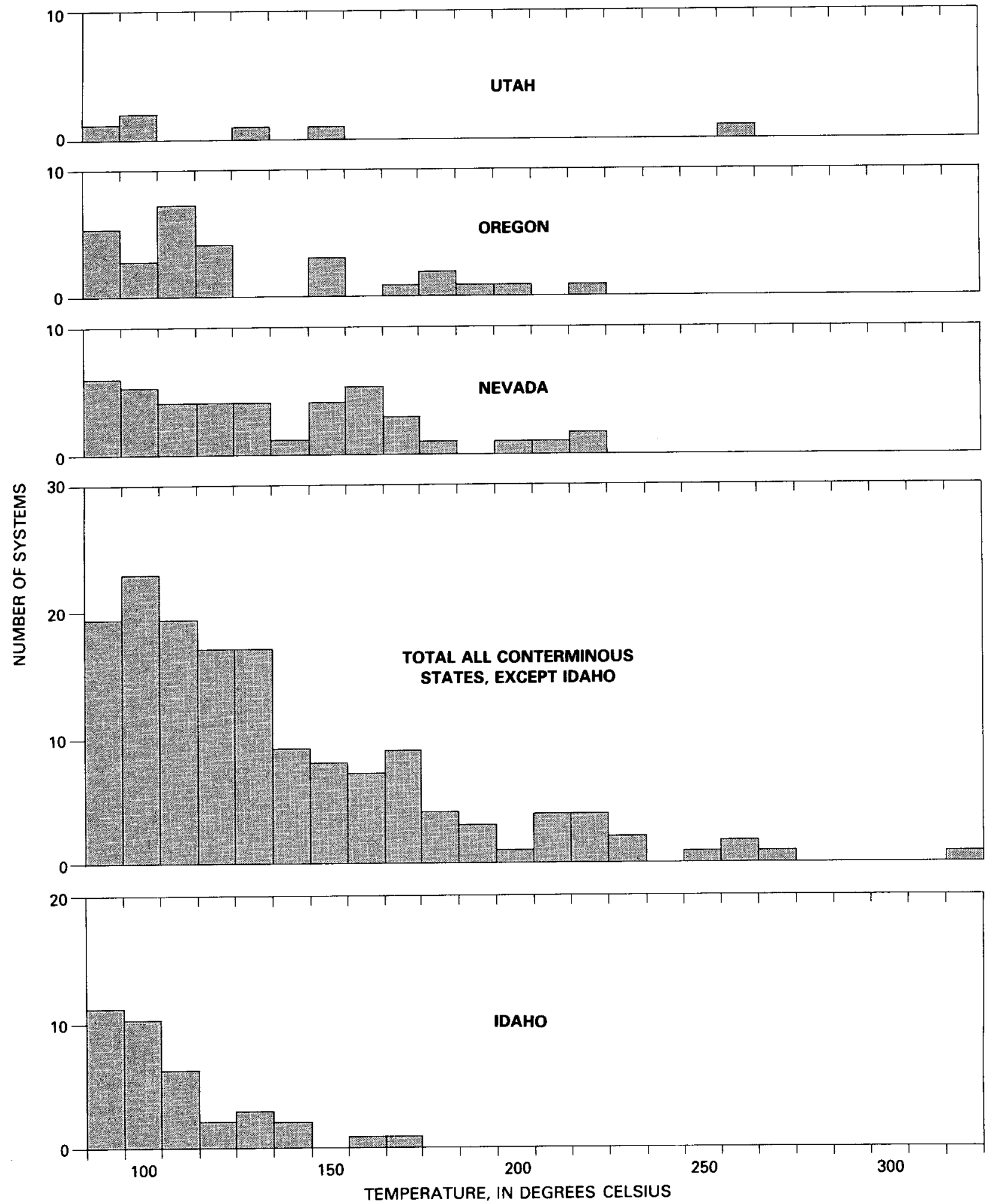

Figure 5.-Histogram of number of hydrothermal systems with reservoir temperatures $\geq 90^{\circ} \mathrm{C}$ (data from Brook and others, 1979). 
TABLE 1.-Geothermal systems in Idaho with calculated reservoir temperatures $\geq 90^{\circ} \mathrm{C}$

[See figure 2 for location of systems. ${ }^{\circ} \mathrm{C}$, degrees Celsius; $\mathrm{km}^{3}$, cubic kilometers; J, joules; avg. temp., average temperature]

\begin{tabular}{|c|c|c|c|c|}
\hline No. & $\frac{\text { System }}{\text { Name }}$ & $\begin{array}{c}\text { Mean } \\
\text { temperature } \\
\left({ }^{\circ} \mathrm{C}\right)\end{array}$ & $\begin{array}{c}\text { Mean } \\
\text { volume } \\
\left(\mathrm{km}^{3}\right)\end{array}$ & $\begin{array}{c}\text { Mean } \\
\text { reservoir } \\
\text { energy } \\
\left(10^{18} \mathrm{~J}\right)\end{array}$ \\
\hline
\end{tabular}

Weiser area (avg. temp. $162^{\circ} \mathrm{C}$ )

White Licks Hot Springs.........

$\begin{array}{rrr}139 & 3.3 & 1.1 \\ 171 & 39.0 & 16.4 \\ 130 & 4.4 & 1.4 \\ 135 & 3.3 & 1.1 \\ 131 & 3.3 & 1.0\end{array}$

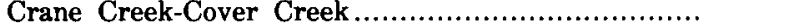

Weiser..................................................

Roystone Hot Springs.....................................

Payette River area........................................

Idaho batholith (avg. temp. $110^{\circ} \mathrm{C}$ )

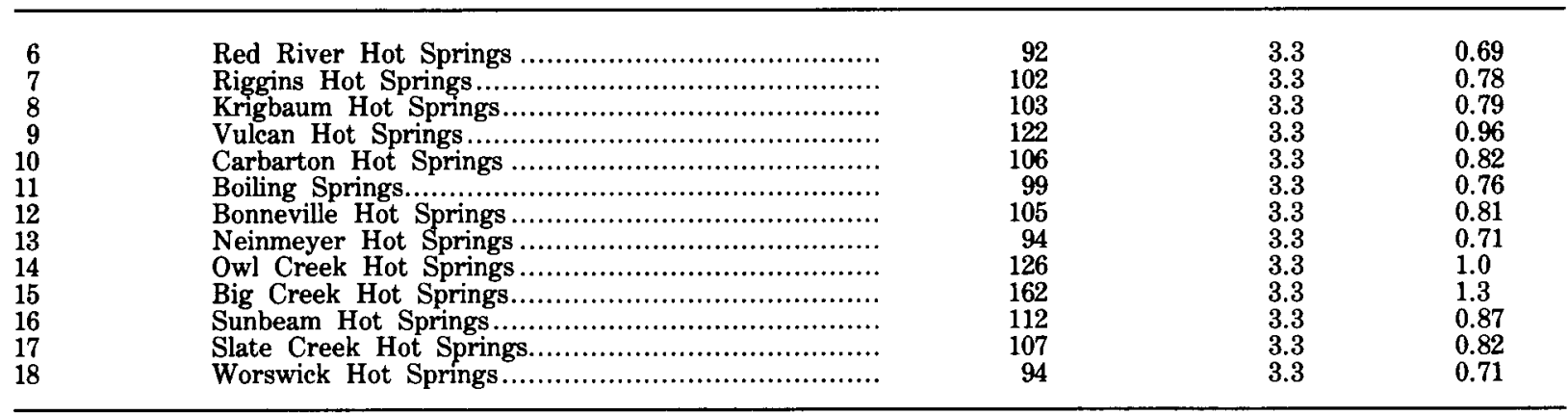

\section{Lost River area}

19 Sharkey Hot Springs

114

3.3

0.89

Camas Prairie (avg. temp. $116^{\circ} \mathrm{C}$ )

\begin{tabular}{|c|c|c|c|c|}
\hline $\begin{array}{l}20 \\
21 \\
22\end{array}$ & 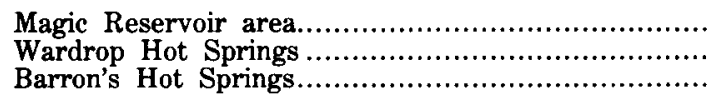 & $\begin{array}{r}149 \\
97 \\
103\end{array}$ & $\begin{array}{l}3.3 \\
3.3 \\
3.3\end{array}$ & $\begin{array}{l}1.2 \\
0.74 \\
0.79\end{array}$ \\
\hline
\end{tabular}

Western Snake River Plain (avg. temp. $107^{\circ} \mathrm{C}$ )

\begin{tabular}{|c|c|c|c|c|}
\hline $\begin{array}{l}23 \\
24 \\
25 \\
26 \\
27 \\
28\end{array}$ & 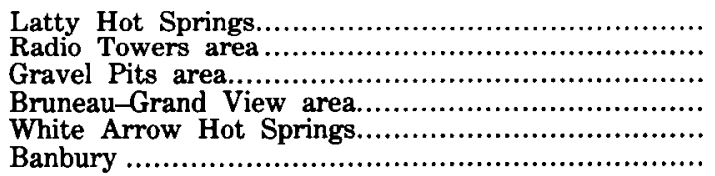 & $\begin{array}{l}124 \\
125 \\
103 \\
107 \\
103 \\
117\end{array}$ & $\begin{array}{r}3.3 \\
3.3 \\
3.3 \\
1830.0 \\
5.8 \\
27.0\end{array}$ & $\begin{array}{r}0.98 \\
0.99 \\
0.79 \\
450.0 \\
1.4 \\
7.4\end{array}$ \\
\hline
\end{tabular}

\section{Owyhee area}

\begin{tabular}{|c|c|c|c|c|}
\hline 29 & 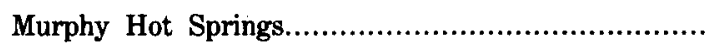 & 103 & 3.3 & 0.79 \\
\hline \multicolumn{5}{|c|}{ Eastern Snake River Plain (avg. temp. $100^{\circ} \mathrm{C}$ ) } \\
\hline $\begin{array}{l}30 \\
31\end{array}$ & 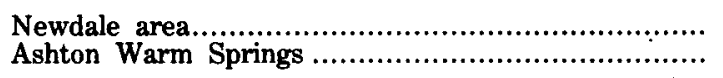 & $\begin{array}{r}100 \\
92\end{array}$ & $\begin{array}{r}89.0 \\
3.3\end{array}$ & $\begin{array}{r}20.0 \\
0.69\end{array}$ \\
\hline \multicolumn{5}{|c|}{ Southeast area (avg. temp. $132^{\circ} \mathrm{C}$ ) } \\
\hline $\begin{array}{l}32 \\
33 \\
34 \\
35 \\
36\end{array}$ & 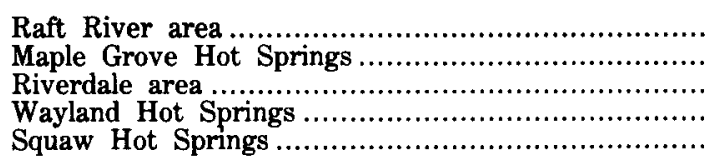 & $\begin{array}{r}149 \\
93 \\
99 \\
113 \\
119\end{array}$ & $\begin{array}{r}21.0 \\
3.3 \\
3.3 \\
3.3 \\
3.3\end{array}$ & $\begin{array}{l}7.4 \\
0.70 \\
0.76 \\
0.88 \\
0.94\end{array}$ \\
\hline
\end{tabular}


area have not been studied in detail, no common element is apparent in the geology of the five systems. Three are in the area of Miocene sedimentary rock and basalt and two are in rocks of the Idaho batholith.

The largest and hottest system in the Weiser Area is Crane Creek-Cove Creek (system 2, fig. 2) (Young and Whitehead, 1975b; McIntyre, 1976). This system is expressed at the surface by springs on Crane and Cove Creeks about $11 \mathrm{~km}$ apart. The similarity of water chemistry, the continuity of geophysical anomalies and extensive alteration leads to the conclusion that one large system underlies the area. The volume of the reservoir is estimated to be $39 \mathrm{~km}^{3}$ (Brook and others, 1979) but geophysical anomalies and alteration are consistent with the existence of a larger reservoir. At $171^{\circ} \mathrm{C}$ calculated reservoir temperature, this is the hottest known system in Idaho. One deep test hole has been drilled in the area but data from the test have not been released.

Thermal waters occur in an area of several square kilometers around Weiser Hot Springs (system 3, fig. 2). Reservoir volume for this system is estimated to be $4.4 \mathrm{~km}^{3}$ and the reservoir temperature $130^{\circ} \mathrm{C}$. The extent of the resistivity low (Hoover and Long, 1976) in this area suggests that the system may be much more extensive than assumed in the resource estimate.

Both the Crane Creek-Cove Creek and Weiser systems are in an area underlain by a thick sequence of Miocene sedimentary rocks and basalt and the springs occur along north-northwest trending fault zones. Both are areas of complex structure with dominant north-northwest systems of faults and folds being intersected by northeast trending faults. Fractured zones in the Miocene and pre-Miocene rocks are the most likely reservoirs. Detailed geophysical surveys should provide targets for exploration drilling.

Little is known about the remaining three geothermal systems in the Weiser area. Roystone Hot Springs (system 4, fig. 2) issue from alluvium near Miocene basalt, but the basalt probably is underlain by rocks of the Cretaceous Idaho batholith at depths of a few hundred meters. White Licks Hot Springs (system 1, fig. 2) and the Payette River area (system 5, fig. 2) are in the Idaho batholith. No geophysical data are available to indicate the extent of these three systems. Any large reservoir that may exist at depth is probably fractured granitic rock.

\section{IDAHO BATHOLITH}

More hydrothermal convection systems are within the Idaho batholith or in areas thought to be underlain by the batholith (fig. 2) than in any other area of Idaho. None of them is known to be large, and Brook and others (1979) assumed each to have the arbitrary minmum reservoir volume $\left(3.3 \mathrm{~km}^{3}\right)$ assigned to systems when no information was available to indicate the dimensions of the reservoir. A wide range of heat flow has been measured in the batholith. Hot springs are most common in the major stream valleys, many of which are thought to be controlled by faults or shear zones. A model that is consistent with all available data assumes fracture permeability permitting water to circulate to depths of 3 or 4 $\mathrm{km}$ where temperatures in the $100^{\circ}-150^{\circ} \mathrm{C}$ range are expected. Twelve of the 13 systems have calculated reservoir temperatures $\leq 126^{\circ} \mathrm{C}$. The exception: Biy Creek Hot Springs (system 15, fig. 2) which issues from Precambrian rock about 7 $\mathrm{km}$ from the nearest outcrop of Idaho batholith. The estimated reservoir temperature of this system is $162^{\circ} \mathrm{C}$, which is substantially higher than any other system in the area of the batholith. An adequate evaluation of the geothermal resource of the Idaho batholith will require detailed studies of representative systems involving hydrological, geological, and geophysical surveys supported by drilling. Current information suggests a large but relatively low-temperature resource distributed through many small systems in the batholith.

\section{WESTERN SNAKE RIVER PLAIN}

The western Snake River Plain (fig. 2) contains 87 percent of the discovered hydrothermal resources of Idaho $\geq 90^{\circ} \mathrm{C}$ and about one-fourth of the nation's geothermal resource in hydrothermal convection systems outside of National Parks. Most of the energy is in the Bruneau-Grand View system and all is in the Mountain Home-Twin Falls area of the plain. Although parts of this area have been intensely studied and several deep holes have been drilled, several fundamental questions relating to the systems remain unanswered.

Estimated reservoir temperatures for systems in the western Snake River Plain range between $103^{\circ}$ and $124^{\circ} \mathrm{C}$ with the Bruneau-Grand View system at $107^{\circ} \mathrm{C}^{1}$ Fifteen heat-flow measurements in

\footnotetext{
'Young and Lewis (1980) concluded that the average reservoir temperature in the Bruneau-Grand View system is about $90^{\circ} \mathrm{C}$.
} 
the area range from -20 to $140 \mathrm{~mW} / \mathrm{m}^{2}$ and average $80 \mathrm{~mW} / \mathrm{m}^{2}$ (Brott and others, 1976), which is lower than on the margin of the plain. Brott and others (1978) attributed the low heat flow over the western Snake River Plain relative to the margins to thermal refraction produced by thick sedimentary rocks underlying the plain and to higher heat generation in the upper crustal material adjoining the plain. They postulated that a large heat source underlies the plain.

Although the model proposed by Brott and others (1978) produces good agreement between the measured and the computed heat flow values, the model does not appear to be completely consistent with other data. A hole drilled on the Snake River Plain $45 \mathrm{~km}$ south of Boise was reported bottomed in granite at about $3.4 \mathrm{~km}$ below the surface (McIntyre, 1979). Above the granite, the section was 25 percent sediments, 9 percent basalt, and 66 percent rhyolite. Thus, at this location, the thickness of Cenozoic rock is only about $3.5 \mathrm{~km}$ rather than the $6 \mathrm{~km}$ assumed in the model proposed by Brott and others (1978) and the abundance of rhyolite indicates an average thermal conductive significantly higher than the 3 TCU (thermal conductivity units) assumed in the model. Therefore, the amount of thermal refraction may be less than computed. If granitic crust underlies the plain at $3.5 \mathrm{~km}$ and 66 percent of the overlying rock is rhyolite, the heat production under the Snake River Plain may be substantial rather than zero as assumed in the model. If the top of the heat source postulated in the thermal model is coincident with the top of the lower crust, the gravity data suggest a much smaller extent than the model assumes and suggest that the area of greatest elevation of the lower crust is confined to the area underlying the plain. Because of these apparent inconsistencies, other thermal models should be considered in addition to that proposed by Brott and others (1978).

The Snake River Plain in the Mountain HomeTwin Falls area is downwarped toward the axis and faulting is locally prominent along the margins. Displacement on the faults is predominantly plain-side down. Subsidence of this area of the plain may be, in part, an isostatic response to the large positive mass anomaly underlying, which may not be completely compensated. Current extension may be concentrated along the margins of the plain with related crustal thinning and resultant high heat flow.
The Bruneau-Grand View geothermal system is unique in Idaho because of its size. Water at temperatures as high as $84.5^{\circ} \mathrm{C}$ is produced from artesian aquifers in Cenozoic volcanic rocks in wells that are as deep as $1100 \mathrm{~m}$ (Young and Whitehead, 1975a). Temperature measurements have not been made in the producing wells, but the temperature of the water produced increases with total depth of the well at an average rate of about $65^{\circ} \mathrm{C}$ per kilometer, which is about equal to the thermal gradient measured in heat-flow holes in the area (Brott and others, 1976). Thus, the wells do not appear to be in a freely convecting hydrothermal system. The increase of temperature with depth suggests that the water may be heated in place and that the temperature gradient at depths greater than about $500 \mathrm{~m}$ is not greatly perturbed by convection. However, the silica and sulfate geothermometers indicate reservoir temperatures of $63^{\circ}-140^{\circ} \mathrm{C}$ with no apparent correlation with well depth or water temperature.

Young and Lewis (1979) proposed a model in which water moves northward through semi-confined aquifers and is heated by an average heat flow of $92 \mathrm{~mW} / \mathrm{m}^{2}$. They calculated that about twothirds of heat entering the bottom of the system is lost at the surface through conduction and spring discharge, and that one-third is carried north by the movement of ground water.

The Bruneau-Grand View system is in an area of complex structure probably produced by an interaction of the forces that have controlled the formation of the western and eastern segments of the plain. The well-defined topographic front that forms the boundary between the plain and Owyhee Mountains terminates here, and to the south and southeast no clearly defined topographic border exists. The southwest edge gravity and magnetic anomalies associated with the plain bend to the south. On the opposite side of the plain, the northern edge begins a wide arc along which it rotates about $80^{\circ}$. A structure extending from the south end of the Owyhee Mountains eastnortheast across the plain is suggested by the gravity data. To the south, the gravity high along the axis of the plain includes a secondary high south of the primary high. The silicic volcanic rocks, which are the primary deep aquifer, are probably highly fractured in this area to produce the permeability that accounts for the productivity of the water wells. The depth to which this permeability extends has not been determined, and, 
thus, the thickness and likely maximum temperatures are not known. More information is needed to define the extent of the Bruneau-Grand View system and the source of the hot water. Although additional deep drilling may discover hot zones in the system, there is no evidence in the existing data to indicate that large volumes of water much hotter than that indicated by the geothermometers will be found associated with the BruneauGrand View system within $3 \mathrm{~km}$ of the surface.

Five smaller systems have been identified in the Mountain Home-Twin Falls area to the east of the Bruneau-Grand View system. In these systems, water is produced from springs or shallow wells with calculated reservoir temperatures ranging from $103^{\circ}$ to $125^{\circ} \mathrm{C}$. However, the geothermometers for some of these waters may be unreliable (Brook and others, 1979). Some or all of these systems may be continuous with the Bruneau-Grand View system. If they are, the resource of hot water is much larger than is indicated in Brook and others (1979). Some of the systems east of Bruneau - Grand View appear to be related to the northeast margin of the plain and the projection of this margin onto the plain, and they may be distinct from the Bruneau-Grand View system. Fractured volcanic rock is the most likely aquifer, and the possiblity exists that significantly higher water temperatures occur at depth than are indicated by the existing geothermometer data. Although warm water occurs widely over most of the western Snake River Plain and may be of considerable value in low-temperature applications, there is no evidence that a high-temperature resource exists outside the Mountain Home-Twin Falls area.

\section{CAMAS PRAIRIE}

Camas Prairie (fig. 2) is an east-trending basin lying north of and parallel to the central part of the Snake River Plain (Mitchell, 1976a). Although separated from the Snake River Plain by a highland, the Mount Bennett Hills, the structure of Camas Prairie and the Mount Bennett Hills is closely related to the Snake River Plain. Two thermal gradient measurements in Camas Prairie yielded gradients of about $90^{\circ} \mathrm{C} / \mathrm{km}$ and heat-flow values of $125 \mathrm{~mW} / \mathrm{m}^{2}$.

Three geothermal systems are known in the area of the prairie that have estimated reservoir temperatures of $\geq 90^{\circ} \mathrm{C}$. Wardrop Hot Spring (sys- tem 21, fig. 2), with an estimated reservoir temperature of $97^{\circ} \mathrm{C}$, is on the northside of the western part of the prairie where Quaternary alluvium is probably underlain at depths of a few tens of meters by the Cretaceous Idaho batholith. Barron's Hot Springs (system 22, fig. 2), estimated reservoir temperature $103^{\circ} \mathrm{C}$, is on the south side of the western part of the prairie where Quaternary alluvium is underlain by an unknown thickness of Cenozoic volcanic rocks. The water chemistry of Wardrop Hot Springs is typical of the Idaho batholith systems. The water from Barron's Hot Springs has slightly higher concentrations of dissolved solids but is within the range of Idaho batholith systems. Although considerable volumes of water at about $100^{\circ} \mathrm{C}$ may occur in the central and western part of Camas Prairie, there is no evidence that indicates the presence of a high-temperature reservoir there.

The Magic Reservoir system (system 20, fig. 2), at the east end of Camas Prairie, has a calculated reservoir temperature of $149^{\circ} \mathrm{C}$, the third highest in Idaho. The Magic Reservoir thermal water has high concentrations of dissolved solids $(1210 \mathrm{mg} / \mathrm{L}$ (milligrams per liter)) with high chloride $(85 \mathrm{mg} / \mathrm{L}$ ) and high bicarbonate $(735 \mathrm{mg} / \mathrm{L}$ ) (Mitchell, 1976a). These values are more like the systems in eastern Idaho than those of western Idaho. No systems $\geq 90^{\circ} \mathrm{C}$ to the west have as much bicarbonate and only one, White Licks Hot Springs, has as much chloride. The Magic Reservoir system is located in an area of complex structure and high heat flow. A wide variety of reservoir rocks, including Paleozoic sedimentary rocks, may underlie the area. A significant high-temperature reservoir may exist there.

\section{OWYHEE AREA}

The Owyhee area (fig. 2) is southwest of the Snake River Plain. Cretaceous intrusive rocks, similar to those of the Idaho batholith, and metamorphic rock crop out in the Owyhee Mountains, but most of the area is overlain by Tertiary silicic volcanic rock. Murphy Hot Springs (system 29, fig. 2), with an estimated reservoir temperature of $103^{\circ} \mathrm{C}$, is the only geothermal system in this area that has a reservoir temperature $\geq 90^{\circ} \mathrm{C}$. No deep holes have been drilled in this area and the deep subsurface geology is not known. Regional heat flow is probably high, and structures 
favorable to the development of hydrothermal convection systems are likely to exist. Additional geophysical exploration and drilling is needed to evaluate the geothermal resource of this area.

\section{EASTERN SNAKE RIVER PLAIN}

The size of the geothermal resource that underlies the eastern Snake River Plain is highly uncertain. Abundant recent volcanic activity, including large rhyolite domes as young as 300,000 years old, and the proximity and possible relationship to the huge geothermal systems in Yellowstone National Park suggest that a large resource might underlie this segment of the plain. However, only two hydrothermal convection systems with estimated reservoir temperatures $\geq 90^{\circ} \mathrm{C}$ have been found in the area of the eastern Snake River Plain. These systems are along the edge of the plain and have estimated reservoir temperatures of only $92^{\circ}$ and $100^{\circ} \mathrm{C}$. Measurement of the regional heat flow in the eastern Snake River Plain is difficult because of the effect of water flowing southwest through the fractured volcanic rock that underlies most of this part of the plain (Brott and others, 1981). One 3-km-deep drill hole and two shallower drill holes on Idaho National Engineering Laboratory are believed to have been drilled deep enough to permit measurement of the heat flow below the effect of the aquifer. One hole about $900 \mathrm{~m}$ deep located $8 \mathrm{~km}$ from the margin of the plain had a gradient in the lower part of the hole of $60^{\circ} \mathrm{C} / \mathrm{km}$ and indicated a heat flow of $110 \mathrm{~mW} / \mathrm{m}^{2}$. The second hole is $600 \mathrm{~m}$ deep and is $25 \mathrm{~km}$ from the margin near East Butte. Here, the gradient in the lower part of the hole is $40^{\circ} \mathrm{C} / \mathrm{km}$ and indicated a heat flow of less than $70 \mathrm{~mW} / \mathrm{m}^{2}$. The average thermal gradient in the deep drill hole about 7 $\mathrm{km}$ from the margin of the plain was about $40^{\circ} \mathrm{C} /$ $\mathrm{km}$. Heat flow measured in the upper part of the hole was $109 \mathrm{~mW} / \mathrm{m}^{2}$. Numerous high heat-flow values have been obtained from measurements in shallow wells near the margins of the eastern Snake River Plain.

Brott and others (1981) have computed the average heat flow below the major aquifer in the eastern Snake River Plain to be $190 \mathrm{~mW} / \mathrm{m}^{2}$. This computation is based on measured heat flow at the surface of the plain and on calculated heating of the water as it moves through the aquifer. They pointed out that this value is twice the average
Basin and Range heat flow and 30 percent higher than the average for the Battle Mountain heatflow high in northern Nevada.

Although much has been learned about the eastern Snake River Plain in recent years, large uncertainties still exist concerning the subsurface geology and the fundamental structure of the plain. Preliminary interpretation of data from an extensive seismic refraction survey of the eastern Snake River Plain indicate a velocity structure similar to that of the western Snake River Plain with an upper crust about $10 \mathrm{~km}$ thick and a thick lower crust (Braile and Smith, 1979). Thus, the entire Snake River Plain appears to be underlain by an upper crust that is thinner and a lower crust that is thicker than adjoining regions to the north and south. These seismic data indicate that the simple crustal-thinning model of the eastern Snake River Plain suggested by Mabey (1978a) on the basis of the gravity anomaly is not valid. A model consistent with crustal structure inferred from the seismic data is consistent with the gravity anomaly (fig. 6). Although the velocity structure under the eastern and western parts of the Snake River Plain are similar, the contrast in gravity and magnetic anomalies and topography suggest important differences. The thinning of the upper crust under the western Snake River Plain appears to be most pronounced along the axis of the plain, whereas under the eastern Snake River Plain, the thinned crust is a broader feature extending well beyond the plain. The magnetic anomalies indicate a much more complexly magnetized crust under the eastern plain. The topography and gravity data indicate that recent subsidence has been greatest along the axis of the western plain and along the margins of the eastern plain.

The computed map of the base of the magnetized crust (fig. 4) does not indicate a high coincident with the eastern Snake River Plain. The magnetotelluric data suggest that the average depth to the conductive layer in the crust is greater under the plain than in the adjoining regions. Thus, these two data sets do not provide support for the presence of high thermal gradient under the eastern Snake River Plain.

The two known hydrothermal convection systems in the area of the eastern Snake River Plain with calculated reservoir temperatures $\geq 90^{\circ} \mathrm{C}$ are along the margin of the plain near its northeast 


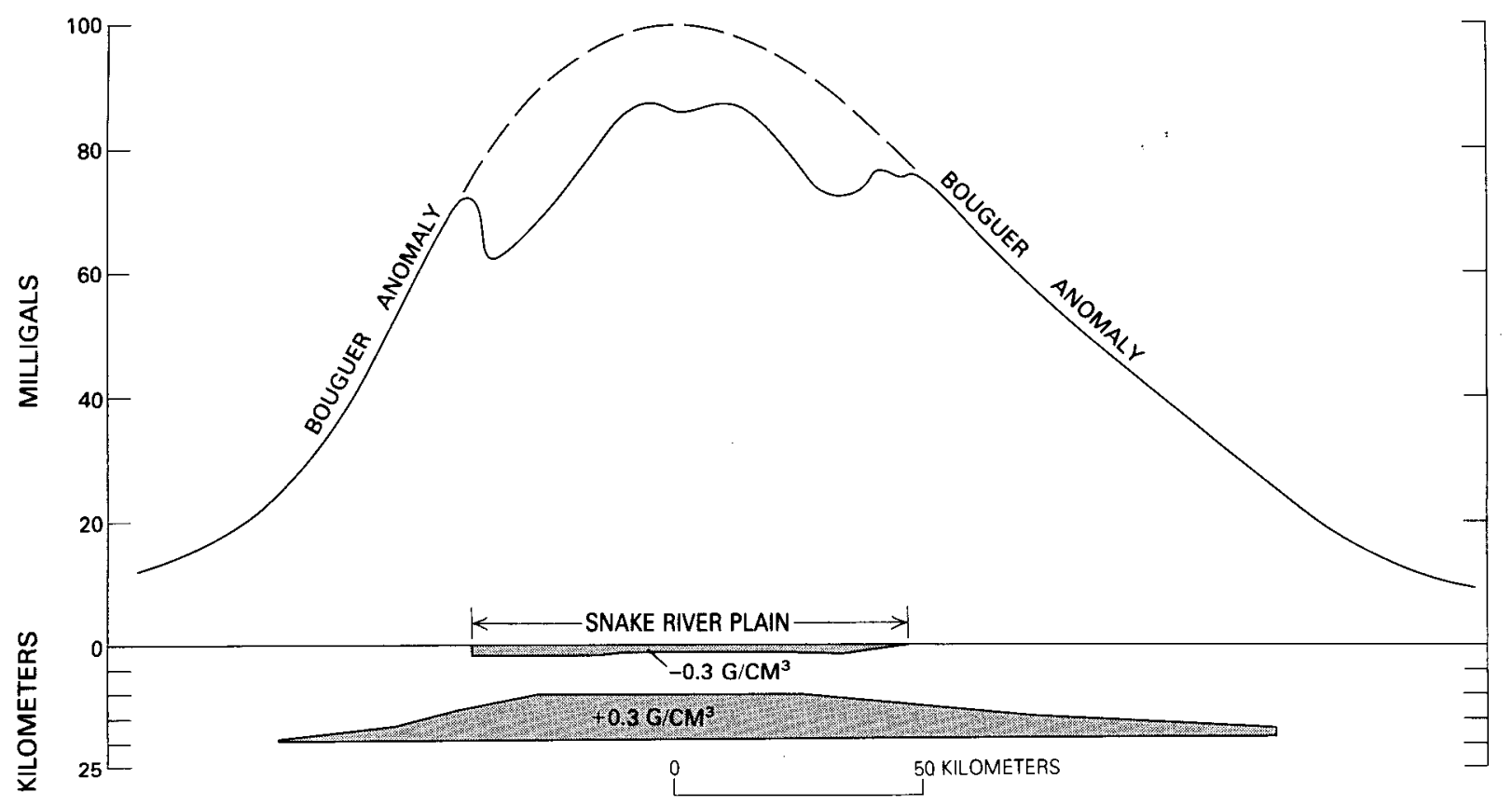

Figure 6.-Profile across the eastern Snake River Plain through Arco and Blackfoot, Idaho, showing Bouguer gravity anomaly and inferred density mode. $\mathrm{g} / \mathrm{cm}^{3}$, grams per cubic centimeter.

end. The Newdale system (system 30, fig. 2) is within the Rexburg caldera complex (B, fig. 2) (Mabey, 1978b; Prostka and Embree, 1978) near the northeast edge of the caldera complex. Thermal water with a calculated reservoir temperature of $100^{\circ} \mathrm{C}$ has been found in several wells as deep as $250 \mathrm{~m}$, and thermal gradient measurements indicate that the anomaly extends over an area of several square kilometers (Brott and others, 1976). The Newdale system probably involves convection in a zone of complex structure associated with the margin of the caldera, perhaps involving an intersection of the caldera edge with a normal fault or with another caldera. Several other areas of thermal water are known within the Rexburg caldera complex but the calculated reservoir temperatures are all less than $90^{\circ} \mathrm{C}$. Heise Hot Springs is near the southern edge of the Rexburg caldera complex and is associated with prominent gravity and magnetic highs. These anomalies have been interpreted as reflecting an uplifted block of pre-Tertiary basement underlain by a large intrusive body that may be young enough to be a source of heat (Mabey, 1978b). The concentration of chloride of the waters is $2400 \mathrm{mg} / \mathrm{L}$. Of the hydrothermal systems in Idaho $\geq 90^{\circ} \mathrm{C}$, only the northern Cache Valley group have a higher chloride content. Although the geothermometers indicate a relatively low reservoir temperature for the Heise Hot Springs system, the geological and geophysical data suggest that the system is unusual and merits special attention.

Ashton Warm Springs (system 31, fig. 2) has an indicated reservoir temperature of $92^{\circ} \mathrm{C}$. The subsurface geological setting is obscured by Pleistocene basalt flows. It is between the Rexburg caldera complex and the Island Park caldera, and as yet undefined caldera structures may underlie the basalt in this area.

Low-temperature thermal waters occur in several other areas near the margins of the eastern Snake River Plain, but available evidence does not suggest that these areas are underlain by a hightemperature resource.

Crustal extension and thinning of the upper crust may have been important in the formation of the eastern Snake River Plain. Crustal extension would be accompanied by high heat flow but when the extension stops, the heat flow eventually will decline and may drop below the original level because of the lowered heat-generating capacity of the thinned crust. A broad low-amplitude topographic high is approximately coincident with the axis of the eastern Snake River Plain. Two expla- 
nations for this high exist: (1) the high is a constructional feature produced by a thicker accumulation of volcanic rock near the axis than along the margins, and (2) the margins are subsiding more than the axis. Most of the surface basalts were erupted from vents along rifts extending from the margin of the plain to near the axis. The distribution of these vents does not suggest that a greater volume of basalt was erupted near the axis. In addition to the basalt flows, sediment derived from the adjoining highlands has been deposited near the margins of the plain and is interlayered with the flows. The topographic low and the underlying sediments along the margins of the plain suggest that the margins of the plain have subsided more than the axis. A more rapid subsidence of the margins of the eastern Snake River Plain suggests that extension of the crust is concentrated along the margins and that heat flow is probably higher there.

Extension normal to the plain would explain the topographic and heat-flow patterns, but there is little evidence in the surface geology of active regional extension normal to the plain. Volcanic rifts and open fractures are common on the eastern Snake River Plain. Most are alined approximately normal to the axis of the plain and parallel to the basin and range structures to the north and south. Apparently, current regional extension is accommodated north of the plain by movement along preexisting listric faults in the upper brittle layer and by ductile extension in the underlying layer. On the plain, this extension produces fissures in the upper layer. The greater subsidence along the margins of the plain relative to the axis might reflect a thinner ductile layer and incomplete isostatic adjustment of the margins of the plain.

The most recent volcanic activity on the eastern Snake River Plain can be classified into two types: eruption of basalt from volcanic rifts and the development of rhyolite calderas and domes. Large volumes of basalt have erupted on the eastern Snake River Plain in Quaternary time and some of the flows are only a few thousand years old. The basalt probably originates at great depth and rises to the surface in narrow conduits with most of the heat released by cooling of the basalt at the surface. Only a small part of the heat in the molten basalt is used in heating rock adjacent to the conduits or stored in magma reservoirs in the upper crust. However, the rhyolite may come from high-level silicic magma chambers that are large reservoirs of heat while they cool. These magma chambers could be major sources of heat on the eastern Snake River Plain (see Smith and Shaw, 1979). The geological and geophysical data in the area of the Rexburg caldera complex (Mabey, 1978b) are consistent with the existence of a high-level magma chamber in this area. Smith and Shaw (1979) have estimated the remaining thermal energyin this system at $8400 \times 10^{18}$ joules, making this the fourth largest energy content in igneous systems in the United States and only slightly less than in Valles caldera system in New Mexico. Although other large caldera systems may underlie the eastern Snake River Plain, most are likely to be older and thus to contain less thermal energy. Big Southern Butte (C, fig. 2) and several smaller buttes to the east are rhyolite domes. Ages of the rhyolite of these buttes range from 0.3 to $1.4 \mathrm{~m} . \mathrm{y}$, with Big Southern Butte the youngest (Kuntz and Dalrymple, 1979). Smith and Shaw (1979) estimated the remaining thermal energy in the big Southern Butte igneous systems at $240 \times 10^{18}$ joules. However, the available geophysical data do not provide any confirmation that a large high-level magma chamber underlies Big Southern Butte or the other buttes on the eastern Snake River Plain.

In 1979, the U.S. Department of Energy drilled a geothermal test well on the Snake River Plain at the Idaho National Engineering Laboratory about $7 \mathrm{~km}$ from the northwest edge of the plain. The hole bottomed at $3155 \mathrm{~m}$ in rhyodacite, which may be either a dense welded tuff or a high-level intrusive (Doherty and others, 1979). ${ }^{2}$ The bottom-hole temperature was $142^{\circ} \mathrm{C}$, the permeability was low below $500 \mathrm{~m}$, and little water could be produced. The hole was located on a zone of geophysical anomalies trending parallel to the northwest margin of the plain. The anomalies were interpreted as reflecting a major boundary between an area along the margins of the plain where pre-Tertiary rock was generally within 2 $\mathrm{km}$ of the surface, and an area to the southeast where the depth and nature of the pre-Tertiary rock was uncertain. Subsequent to the drilling, Doherty and others (1979) have proposed that the well was drilled in intracaldera fill of a large caldera. The caldera they proposed extends north from Big Southern, Cedar, Middle, and East

\footnotetext{
${ }^{2} \mathrm{~L}$. A. McBroome (oral commun., 1981) reports that this rock is 12.6 m.y. old.
} 
Buttes and has a maximum dimension of about 30 $\mathrm{km}$. Kuntz and Covington (1979) inferred that several other large calderas underlie the eastern Snake River Plain. Prostka (1979) also postulated several calderas underlying the eastern Snake River Plain.

Extensive geological and geophysical surveys and drilling in recent years have failed to provide any direct evidence for the existence of a major high-temperature geothermal resouce underlying the central part of the eastern Snake River Plain. However, exploration for geothermal energy on the eastern Snake River Plain is difficult and much more work must be done before the resource in this area can be evaluated with confidence.

The primary information to be considered in estimating the geothermal resource underlying the eastern Snake River Plain is: (1) abundant evidence of recent volcanic activity and a suggested relationship to the known huge geothermal resource in Yellowstone National Park, (2) warm water in springs and shallow wells near the margins of the plain and heating of the water in the major aquifer under the plain, (3) three boreholes on the plain drilled through the aquifer in which were modest thermal gradients and heat flow, (4) an indication in the $P$-wave delay data and the low seismisity that the temperatures at depth under the plain may be higher than adjoining areas, (5) the absence of any indication of anomalously high temperatures under the plain in the interpretation of the magnetotelluric and magnetic data, (6) an indication in the topography and subsurface data that the margins of this plain may have subsided more than the axis, and (7) geophysical and borehole information on the subsurface that can be used to infer where the structure would permit the development of hydrothermal convection systems. These data can be interpreted in several ways.

Brott and others (1981) concluded from their thermal studies in the eastern Snake River Plain that the heat flow below the major aquifer is high and that a large geothermal potential exists below the cooling effect of the aquifer. They assumed that the aquifer is from 200 to $300 \mathrm{~m}$ thick. Thus, they suggested that a considerable resource may exist within $3 \mathrm{~km}$ of the surface.

Four holes drilled to depths of more than 600 $m$ for geothermal information are only a small sample of the large area of the eastern Snake River Plain but they provide the most direct tem- perature and geologic data available on the subsurface. One hole about $50 \mathrm{~km}$ northeast of Idaho Falls was drilled mostly in fractured rhyolite and appeared to be in the regional aquifer to the total depth of $700 \mathrm{~m}$. The thermal gradient was disturbed by water movement, but the average temperature in the aquifer was about $15^{\circ} \mathrm{C}$. Three holes drilled on Idaho National Engineering Laboratory appear to have been drilled through the regional aquifer. The temperature in the aquifer ranged from $13^{\circ}$ to $23^{\circ} \mathrm{C}$, the gradients below the aquifer ranged from $42^{\circ}$ to $56^{\circ} \mathrm{C} / \mathrm{km}$, and the heat flow below the aquifer ranged from 66 to $110 \mathrm{~mW} /$ $\mathrm{m}^{2}$ with the lowest values for the hole nearest the axis of the plain. The deepest hole was $3157 \mathrm{~m}$ with a bottom-hole temperature of $142^{\circ} \mathrm{C}$. The hydraulic conductivity below the regional aquifer was generally low and little water could be produced.

Although any conclusion about the entire eastern Snake River Plain based on these four holes should be drawn with great care, the data from these holes do not provide support for a high heat flow under the central part of the plain. Nor is there evidence in the temperatures of the regional aquifer that major heating of the water is occurring in the central part of the plain. The inability of the deep hole to produce fluid indicates that, at least in one location, the deep structure is not favorable for the development of hydrothermal convection systems.

Although an uncertainty exists concerning the likelihood of a major geothermal resource occurring under the central part of the eastern Snake River Plain, along the margins conditions appear favorable for the development of geothermal systems. Here, regional heat flow is high and complex structures favoring deep circulation of water are likely to exist at the intersection of the margins of the plain with calderas on the plain and with basin and range structures approximately normal to the plain. Geophysical data suggest that pre-Cenozoic sedimentary rocks that are known to be reservoirs south of the plain extend at least a short distance onto the plain. Exploration should progress from the margins of the plain toward the axis.

\section{ISLAND PARK AREA}

The Island Park area (fig. 2) as used in this report is the area lying between the northeast end of the Snake River Plain and Yellowstone National 
Park. It is approximately coincident with the Upper Henrys Fork basin. Except for the north edge, the entire area is underlain by Cenozoic volcanic rocks that locally are overlain by Quaternary alluvium.

Several thermal springs have been identified in the Island Park area (Whitehead, 1978), but none have water temperatures $\geq 25^{\circ} \mathrm{C}$ or geochemical temperatures $\geq 90^{\circ} \mathrm{C}$. The average annual precipitation in this area is estimated to be $90 \mathrm{~cm}$ and the water table is commonly near the surface. The volcanic rocks are probably highly fractured, and the movement of nonthermal water in these fractures is likely to result in mixing between cold ground water moving down and laterally with ascending thermal waters. Thus, the absence of surface water with high measured or geochemical temperatures does not preclude that high temperatures exist at depth.

The primary indication that a large geothermal resource might occur in the area is the geology (Christiansen, 1975). Between about 1 and 2 million years ago, large volumes of rhyolite were erupted from the Island Park area during three cycles of activity associated with the development of the Island Park caldera system (A, fig. 2). This rhyolite is presumed to have come from a large rhyolitic magma body underlying the caldera system. Although this body has been cooling for more than a million years, considerable thermal energy must remain in the system. Smith and Shaw (1979) estimated that the system contains $16,850 \times 10^{18}$ ioules of thermal energy. Of the igneous systems in the United States, this energy content is second only to that of the Yellowstone caldera system and is more than twice that of the third largest system-Valles caldera. Although anticipated temperatures are lower than for younger systems, a large geothermal resource might exist.

The geophysical data from the area are inconclusive. A comparison of the geophysical anomalies with two other caldera systems in the region illustrates the problem of interpreting the data from the Island Park area. To the east, the Yellowstone caldera system is younger and larger. To the southwest, the Rexburg caldera complex is of similar size but is older. Large gravity lows are related to both the Yellowstone and the Rexburg features but no large gravity anomaly is coincident with the Island Park caldera system. The Yellowstone gravity low has been interpreted as reflecting a molten rhyolite body (Eaton and others,
1975). The Rexburg low is thought to reflect primarily the rock filling the caldera, but some effect of a solidified magma body also may be present (Mabey, 1978b). The absence of a gravity anomaly at Island Park can be explained in either of two basic ways: (1) There may be no large lateral density contrasts. If there is thick caldera fill or a large intrusive body underlying the area, they are enclosed in rock of approximately equal density. (2) Positive anomalies (basalt) and negative mass anomalies (rhyolite and sediments) of approximate equal amplitude occur and the total effect is near zero.

The regional free-air anomaly values in the Island Park area suggest that the area is in approximate isostatic equilibrium with the areas to the north, west, and south. On the east and extending a short distance into the Island Park area is the large gravity low associated with Yellowstone caldera system. The suggestion was made first by Eaton and others (1975) and later was expanded upon by Brott and others (1981) that the formation of the eastern Snake River Plain could in part relate to the cooling and contraction of a hot mass underlying the plain. The Island Park area, which is intermediate between the Yellowstone caldera system and the Snake River Plain in both gravity and topography, may be underlain by a partly cooled mass. Perhaps with further cooling and contraction, the area will subside and a Bouguer gravity high will develop.

The magnetic intensity in the Island Park area is generally low, suggesting more of an affinity with the Yellowstone caldera system than with the eastern Snake River Plain, but areas of low intensity of almost equal area do occur on the eastern Snake River Plain. Computations of the elevation of the Curie isotherm surface for southeastern Idaho (Bhattacharyya and Mabey, 1980) did not produce a determination in the central part of the Island Park area, but a determination near the north border and outside of the magnetic low is $11 \mathrm{~km}$ below sea level, or about $13 \mathrm{~km}$ below the land surface. Within the central part of the area, the Curie isotherm surface may be significantly higher 'but not likely as high as under the Yellowstone caldera system where the Curie isotherm is computed to be $5-6 \mathrm{~km}$ below the land surface (Bhattacharyya and Leu, 1975).

The Island Park caldera system is a major resistivity anomaly. Audio-magnetotelluric measurements (Hoover and Long, 1976) indicated that the 
resistivity of the rocks within $2 \mathrm{~km}$ of the surface are generally more than $100 \mathrm{ohm}-\mathrm{m}$ (ohm meter) and as high as $1000 \mathrm{ohm}-\mathrm{m}$. Deeper probing magnetotelluric sounding (Stanley and others, 1977) indicates that rock with high resistivity (more than $500 \mathrm{ohm}-\mathrm{m}$ ) extends to the depths perhaps as much $8 \mathrm{~km}$. In contrast, resistivities in the Yellowstone caldera system are low, with resistivities generally less than $50 \mathrm{ohm}-\mathrm{m}$ in the upper $5 \mathrm{~km}$ and less than 5 ohm-m at depths greater than 5 $\mathrm{km}$.

The resistivity data from the Island Park area can be interpreted in two quite difference ways as an indication of temperatures at depth. Hoover and Long (1976, p. 1063) concluded that the high resistivities determined from audio-magnetotelluric and telluric current surveys "implies that the caldera has cooled, that there is little rock alteration, and that the area is not now a very promising exploration target." W. D. Stanley (oral commun., 1979), on the other hand, postulated that the high resistivities at depth under the Island Park caldera system reflect zones from which water has been purged by high temperatures.

Few large earthquakes occur in the Island Park area. The seismic activity is thus similar to the eastern Snake River Plain which is almost void of earthquakes, as contrasted with intense earthquake activity in some areas of the Yellowstone caldera system.

Although no data are available for the Island Park area to define the deep thermal gradient, the geology and measured thermal gradients in adjoining areas suggest that the thermal gradients below the hydrologically disturbed zone are likely to be at least $50^{\circ} \mathrm{C} / \mathrm{km}$ and perhaps considerably higher. Regional tectonic patterns suggest that the area is likely to be extending. The resulting fracture systems should provide conduits for deep circulation of water and the development of hydrothermal convection systems. The existence of large volumes of rock and water at temperatures higher than $150^{\circ} \mathrm{C}$ within $3 \mathrm{~km}$ of the surface appears likely. Deep drilling will be required to evaluate the geothermal resources of the Island Park area but the existing data suggest that it is one of the most promising areas in southern Idaho.

\section{LOST RIVER AREA}

The Lost River area (fig. 2), which is east of the Idaho batholith and north of the Snake River
Plain, contains only one geothermal system with an estimated reservoir temperature $\geq 90^{\circ} \mathrm{C}$. Early Tertiary intrusive and extrusive rocks are common in this area but younger volcanic rocks are not. The elevation of this region is the highest in Idaho, and the movement of cold ground water downward and away from this high area may inhibit the development of geothermal systems in the near surface. The regional heat flow has not been defined, but the magnetic data suggest a high in the Curie isotherm surface over most of this region. An active seismic zone extends across the northern part of the area and evidence of young normal faulting occurs throughout much of the area. Active extension with attendant crustal thinning and high heat flow is suggested. Large gravity lows occur in Lemhi, Birch Creek, Pahsimeroi, and Little Lost River Valleys and smaller lows in the Big Lost River Valley. These anomalies reflect thick accumulations of Cenozoic rock that may act as thermal blankets and increase the temperature at depth under the valleys. The Cenozoic rocks underlying the valleys are potential reservoir rocks, as are Paleozoic and Precambrian sedimentary rocks that are several kilometers thick. Although the direct indicators of a geothermal resource are lacking, the area offers sufficient promise to justify additional exploration to determine the regional heat flow.

\section{SOUTHEASTERN IDAHO}

Southeastern Idaho (fig. 2) as used here is south of the eastern Snake River Plain. It is an area of basin and range structure with Cenozoic fill in the basins as much as $4 \mathrm{~km}$ thick. The Albion Mountains have a core of Precambrian metamorphic rock and the next east, the Cottrel and Jim Sage Mountains, is entirely Cenozoic volcanic and sedimentary rocks. The ranges to the east are predominantly Precambrian, Paleozoic and Mesozoic sedimentary rocks locally overlain by Cenozoic sedimentary rocks. One area of young volcanic rocks, Blackfoot lava fields, is of special geothermal interest.

Five geothermal systems with calculated reservoir temperatures of $\geq 90^{\circ} \mathrm{C}$ have been identified in this area. The Raft River system (Williams and others, 1976) (system 32, fig. 2) is near the western edge of the area and has measured reservoir temperatures of from $146^{\circ}$ to $149^{\circ} \mathrm{C}$. Water from this system may be used by the U.S. Department of Energy in a demonstration project to produce 
electricity from this relatively low-temperature water, and it is the most intensely studied system in Idaho. The other four systems with calculated reservoir temperatures from $93^{\circ}$ to $119^{\circ} \mathrm{C}$ are along the Bear River within $27 \mathrm{~km}$ of Preston (Mitchell, 1976a).

Heat-flow data are sparse in southeastern Idaho, but the available values are generally low except near the margins of the Snake River Plain and in the vicinity of the Raft River system where a background value of about $100 \mathrm{~mW} / \mathrm{m}^{2}$ is indicated. Although other local heat-flow anomalies of substantial extent may exist in the area, the average heat flow is probably less than $80 \mathrm{~mW} / \mathrm{m}^{2}$.

The primary reservoir of the Raft River system is in fractured Tertiary sedimentary rocks overlying a less disturbed pre-Tertiary basement complex (Williams and others, 1976; Mabey, Hoover, and others, 1978). The fracturing of the reservoir rock has been interpreted as resulting from movement along a low-angle detachment fault near the contact between the Tertiary sedimentary rocks and the underlying basement. Deeper circulation may be controlled by a northeast-trending shear zone. Both a magnetotelluric sounding and the magnetic data have been interpreted as indicating a high-temperature anomaly in the crust. The extent of the Raft River system has not been determined, but reservoir volume is estimated to be about $20 \mathrm{~km}^{3}$. Other similar systems may occur around the Albion Mountains.

Gravity data (Peterson and Oriel, 1970) suggest that three of the four systems near Preston are along normal faults bounding a prism of Cenozoic sediments about $2 \mathrm{~km}$ thick underlying northern Cache Valley. No information exists on the volume of the reservoirs associated with these systems. Two of them-Squaw Springs and Wayland Hot Springs (systems 35 and 36, fig. 2; Wayland Hot Springs is called Battle Creek Hot Springs in Mitchell, 1976a)_ are $1.6 \mathrm{~km}$ apart, have similar indicated reservoir temperatures and water chemistry $(9,000-12,000 \mathrm{mg} / \mathrm{L}$ total dissolved solids). They are along the same fault suggested by gravity data and may be a part of the one large system. Possible reservoir rocks are lower units in the Tertiary section or pre- Tertiary rocks. No evidence of a local heat source has been reported and the water is probably heated by deep circulation. Although the area merits more study, there is no suggestion in the available data of a large reservoir of water at a temperature higher than $120^{\circ} \mathrm{C}$.

The Riverdale system (system 34, fig. 2; Ben Meek Well in Mitchell, 1976a) has a lower calculated reservoir temperature and lower concentration of dissolved solids. Structural control and reservoir rocks for this system are likely to be similar to those of the system on the west side of the valley. Mitchell (1976a) described the northeasttrending Mink Creek-Bear River lineament passing through the three Cache Valley systems and suggests that the intersection of the lineament with a north-trending normal fault may control the hot-spring activity on the west side of the valley. The same situation exists on the east side of the valley. Other northeast-trending features parallel to the axis of the eastern Snake River Plain can be identified in southern Idaho, and their intersection with north-trending fault zones merit special attention in geothermal exploration.

Maple Grove Hot Spring (system 33, fig. 2) is located where a deep canyon of the Bear River cuts into Paleozoic sedimentary rock. The calculated reservoir temperature is lower $\left(93^{\circ} \mathrm{C}\right)$ and the concentration of dissolved solids is lower (2000 $\mathrm{mg} / \mathrm{L}$ ) than the waters of the Cache Valley systems. Although several lower temperature hot springs occur about $2 \mathrm{~km}$ to the north, there is no evidence that a large high-temperature reservoir exists in this area.

Several oil tests drilled in the overthrust belt of southeastern Idaho have reported high temperatures and large flows of water from pre-Tertiary rocks. Not enough information has been made public to evaluate the possible resource found in this drilling.

Quaternary basalt flows occur in several valley areas in a north-trending zone about $35 \mathrm{~km}$ wide and about $100 \mathrm{~km}$ long extending from near the southeast margin of the Snake River Plain to a few kilometers south of Soda Springs. The known vents for these flows are considerably less extensive than the flows but are widespread. Some of the flows are slightly deformed and inversely magnetized, indicating that they are more than 700,000 years old. The age of the youngest basalt flows have not been determined, but most of the basalt is probably more than 50,000 years old. Near the center of the zone of basalt flows is the Blackfoot lava field (D, fig. 2), which appears to have been the source area for much of the basalt. Here, in addition to about 25 basalt cinder cones 
and vents are several rhyolite domes. Some of these domes have been dated at about 50,000 years B.P. (before the present; Leeman and Gettings, 1977).

The geophysical data from the Blackfoot lava field have been interpreted in several ways. Mabey and Oriel (1970) concluded that the gravity low and magnetic high could be produced by a volcanic collapse related to the withdrawal of magma at depth, but they recognized that part of each anomaly might be produced by an underlying intrusive body. Leeman and Gettings (1977) interpreted the same data to indicate a large hot laccolithic body at shallow depth. Audio-magnetotelluric data (D. B. Hoover, written commun., 1975) show that the resistivities to depths of $2 \mathrm{~km}$ are high, but magnetotelluric data (J. E. O'Donnell, written commun., 1980) indicate a highly conductive zone at depths of less than $10 \mathrm{~km}$.

Numerous thermal springs occur in the general area of the Blackfoot lava field and a high temperature has been reported in an oil test a few kilometers to the north; however, none of the waters from springs or shallow wells have temperatures higher than $42^{\circ} \mathrm{C}$ and calculated reservoir temperatures are generally low (Mitchell, 1976c). Large volumes of cold ground water are moving through the basalt aquifers and may be mixing with ascending hot water and masking surface evidence of high temperature underlying the Blackfoot lava field. Geological and geophysical evidence of a large thermal anomaly in the area suggest that it is the most promising area in southeastern Idaho for the occurrence of large high-temperature geothermal reservoirs. Geothermal gradient surveys in drill holes several hundred meters deep will be required to confirm or refute the existence of a major geothermal anomaly.

\section{CONCLUSIONS}

Large volumes of hot water are known to occur in southern Idaho. The large-scale development of this resource for direct application to space heating and industrial processes is highly likely. Thus, geothermal energy appears to be an important future source of energy in southern Idaho. Reservoirs of water at the higher temperatures that are currently considered necessary for the commercial generation of electricity have not been found in southern Idaho. Exploration for geothermal energy in Idaho is unusually difficult because of an extensive cover of young sedimentary and volcanic rocks in many areas of interest and problems related to obtaining heat-flow and thermal-gradient data undisturbed by ground-water movement. However, on the basis of the geology and geophysical anomalies, several areas have been identified as favorable for the occurrence of high-temperature resources and additional exploration in these areas has promise of locating a large high-temperature resource.

\section{REFERENCES CITED}

Armstrong, R. L., Leeman, W. P., and Malde, H. E., 1975, Quaternary and Neogene volcanic rocks of the Snake River Plain, Idaho: American Journal of Science, v. 275, p. 225251.

Bhattacharyya, B. K., and Leu, L. K., 1975, Analysis of magnetic anomalies over Yellowstone National Park-Mapping of Curie-point isothermal surface for geothermal reconnaissance: Journal of Geophysical Research, v. 80, p. 44614465.

Bhattacharyya, B. K., and Mabey, D. R., 1980, Interpretation of magnetic anomalies over southern Idaho using generalized multibody models: U.S. Geological Survey Open-File Report 80-457, 49 p.

Blackwell, D. D., 1978, Heat flow and energy loss in the Western United States, in Smith, R. B., and Eaton, G. P., eds., Cenozoic tectonics and regional geophysics of the Western Cordillera: Geological Society of America Memoir 152 , p. $175-208$.

Bowen, R. G., and Blackwell, D. D., 1975, The Cow Hollow geothermal anomaly, Malheur County, Oregon: The Ore Bin, v. 37, p. 109-121.

Braile, L. W., and Smith, R. B., 1979, The structure of the crust in the Yellowstone-Snake River Plain area and adjacent provinces and implications for crustal evolution: EOS, v. 60, p. 941 .

Brook, C. A., Mariner, R. H., Mabey, D. R., Swanson, J. R., Guffanti, Marianne, and Muffler, L. J. P., 1979, Hydrothermal convection systems with reservoir temperatures $\geq 90^{\circ} \mathrm{C}$, in Muffler, L. J. P., ed., Assessment of geothermal resources of the United States-1978: U.S. Geological Survey Circular 790, p. 18-85.

Brott, C. A., Blackwell, D. D., and Mitchell, J. C., 1976, Geothermal investigations in Idaho, part 8, Heat flow study of the Snake River Plain, Idaho: Idaho Department of Water Resources Water Information Bulletin 30, 195 p.

Brott, C. A., Blackwell, D. D., and Mitchell, J. C., 1978, Tectonic implications of the heat flow of the western Snake River plain: Geological Society of America Bulletin, v. 89, p. 1697-1707.

Brott, C. A., Blackwell, D. D., and Ziagos, J. P., 1981, Thermal and tectonic implications of heat flow in the eastern Snake River Plain, Idaho: Journal of Geophysical Research, v. 86, no. B12, p. 11709-11734.

Christiansen, R. L., 1975, Origin and geothermal potential of Island Park, eastern Idaho: Geological Society of America Abstracts with Programs, v. 7, p. 595-596. 
Christiansen, R. L., and McKee, E. H., 1978, Late Cenozoic volcanic and tectonic evolution of the Great Basin and Columbia intermountain regions, in Smith, R. B., and Eaton, G. P. eds., Cenozoic tectonics and regional geophysics in the Western Cordillera: Geological Society of America Memoir 152, p. 283-312.

Doherty, D. J., McBroome, L. A., and Kuntz, M. A., 1979, Preliminary geological interpretation and lithologic log of the exploratory geothermal Test Well (INEL-1), Idaho National Engineering Laboratory, eastern Snake River Plain, Idaho: U.S. Geological Survey Open-File Report 79 $1248,10 \mathrm{p}$.

Eaton, G. P., Christiansen, R. L., Iyer, H. M., Pitt, A. M., Mabey, D. R., Blank, H. R., Zietz, Isidore, and Gettings, M. E., 1975, Magma beneath Yellowstone National Park: Science, v. 188 , p. $787-796$.

Eaton, G. P., Prostka, H. J., Oriel, S. S., and Pierce, K. L., 1976, Cordilleran thermal tectonic anomaly; I. Geophysical and geological evidence of coherent late Cenozoic intraplate magmatism and deformation [abs.]: Geological Society of America Abstracts with Programs, v. 8, no. 6, p. 850.

Eaton, G. P., Wahl, R. R., Prostka, H. J., Mabey, D. R., and Kleinkopf, M.D., 1978, Regional gravity and tectonic patterns; Their relation to Late Cenozoic epeirogeny and lateral spreading in the Western Cordillera: Geological Society of America Memoir 152, p. 51-92

Evans, J. R., and Iyer, H. M., 1979, Deep structurel under Yellowstone and the eastern Snake River Plain from teleseismic $P$-wave delays: EOS, v. 60, n. 46 , p. 942.

Fitterman, D. V., 1979, Geomagnetic induction study across the eastern Snake River Plain, Idaho: EOS, v. 60, no. 46 , p. 944 .

Hoover, D. B., and Long, C. L., 1976, Audio-magnetotelluric methods in reconnaissance geothermal exploration: United Nations symposium on the development and use of geothermal resources, 2d, San Francisco, Calif., 1975, Proceedings, v. 2. p. 1059-1064.

Kuntz, M. A., and Covington, H. R., 1979, Do basalt structures and topographic features reflect buried calderas in the eastern Snake River Plain: EOS, v. 60, no. 46, p. 945.

Kuntz, M. A., and Dalrymple, G. B., 1979, Geology, geochronology, and potential volcanic hazards in the Lava Ridge-Hells Half Acre area, eastern Snake River Plain, Idaho: U.S. Geological Survey Open-File Report 79-1657, 72 p.

Lachenbruch, A. H., and Sass, J. H., 1978, Models of an extending lithosphere and heat flow in the Basin and Range province, in Smith, R. B., and Eaton, G. P., eds., Cenozoic tectonics and regional geophysics of the Western Cordillera: Geological Society of America Memoir 152, p. 209-250.

Leeman, W. P., and Gettings, M. E., 1977, Holocene rhyolite in SE Idaho and geothermal potential: EOS v. 58 , no. 12, p. 1249.

Mabey, D. R., 1976, Interpretation of a gravity profile across the western Snake River Plain, Idaho: Geology, v. 4, p. $53-55$.

1978a, Regional gravity and magnetic anomalies in the eastern Snake River Plain, Idaho: U.S. Geological Survey Journal of Research, v. 6, no. 5, p. 553-562.

$-1978 b$, Gravity and aeromagnetic anomalies in the Rexburg area of eastern Idaho: U.S. Geological Survey OpenFile Report 78-382, 19 p.
Mabey, D. R., Hoover, D. B., O'Donnell, J. E., and Wilson, C. W., 1978, Reconnaissance geophysical studies of the geothermal system in southern Raft River Valley, Idaho: Geophysics, v. 43, no. 7, p. 1470-1484.

Mabey, D. R., and Oriel, S. S., 1970, Gravity and magnetic anomalies in the Soda Springs region, southeastern Idaho: U.S. Geological Survey Professional Paper 646-E, 15 p.

Mabey, D. R., Zietz, I., Eaton, G. P., and Kleinkopf, M. D., 1978, Regional magnetic patterns in part of the Cordillera in the Western United States, in Smith, R. B., and Eaton, G. P., eds., Cenozoic tectonics and regional geophysics of the Western Cordillera: Geological Society of America Memoir 152, p. 93-106.

McIntyre, D. H., 1976. Photogeologic map of Cambridge quadrangle and western half of the Council quadrangle, western Idaho: U.S. Geological Survey Open-File Report 76857.

1979, Preliminary description of Anschutz Federal No. 1 drill hole, Owyhee County, Idaho: U.S. Geological Survey Open-File Report 79-651, $14 \mathrm{p}$.

Mitchell, J. C., 1976a, Geothermal investigations in Idaho, part 7, Geochemistry and geologic setting of the thermal waters of the Camas Prairie area, Blaine and Camas Counties, Idaho: Idaho Department of Water Resources Water Information Bulletin 30, $44 \mathrm{p}$.

$1976 \mathrm{~b}$, Geothermal investigations in Idaho, part 5, Geochemistry and geologic setting of the thermal waters of the northern Cache Valley area, Franklin County, Idaho: Idaho Department of Water Resources Water Information Bulletin $30,47 \mathrm{p}$.

1976c, Geothermal investigations in Idaho, part 6, Geochemistry and geologic setting of the thermal and mineral water of the Blackfoot Reservoir area, Caribou County, Idaho: Idaho Department of Water Resources Water Information Bulletin 30, $47 \mathrm{p}$.

Mitchell, J. C., Johnson, L. L., and Anderson, J. E., 1980, Geothermal investigations in Idaho, part 9, Potential for direct heat application of geothermal resources: Idaho Department of Water Resources Water Information Bulletin $30,396 \mathrm{p}$.

Muffler, L. J. P., ed., 1979, Assessment of geothermal resources of the United States-1978: U.S. Geological Survey Circular $790,163 \mathrm{p}$.

Peterson, D. L., and Oriel, S. S., 1970, Gravity anomalies in Cache Valley, Cache and Box Elder Counties, Utah, and Bannock and Franklin Counties, Idaho, in Geological Survey Research, 1970: U.S. Geological Survey Professional Paper 700-C, p. C114-C118.

Prostka, H. J., 1979, Buried Pliocene calderas of the eastern Snake River Plain: EOS, v. 60, no. 46, p. 945.

Prostka, H. J., and Embree, G. F., 1978, Geology and geothermal resources of the Rexburg area, eastern Idaho: U.S. Geological Survey Open-File Report 78-1009, 15 p.

Smith, R. B., 1978, Seismicity, crustal structure, and intraplate tectonics of the interior of the Western Cordillera, in Smith, R. B., and Eaton, G. P., eds., Cenozoic tectonics and regional geophysics of the Western Cordillera: Geological Society of America Memoir 152, p. 111-144.

Smith, R. L., and Shaw, H. R., 1979, Igneous-related geothermal systems, in Muffler, L. J. P., ed., Assessment of geothermal resources of the United States-1978: U.S. Geological Survey Circular 790, p. 12-17. 
Stanley, W. D., Boehl, J. E., Bostick, F. X., and Smith, H. W., 1977, Geothermal significance of magnetotelluric soundings in the eastern Snake River Plain-Yellowstone region: Journal of Geophysical Research, v. 82, p. 25012514.

Urban, T. C., and Diment, W. H., 1975, Heat flow on the south flank of the Snake River rift [abs.]: Geological Society of America Abstracts with Programs, v. 7, p. 648.

Whitehead, R. L., 1978, Water resources of the upper Henrys Fork Basin in eastern Idaho: Idaho Department of Water Resources Water Information Bulletin 46, $91 \mathrm{p}$.

Wier, Stuart, 1979, Geomagnetic variation anomalies on the central Snake River Plain: EOS, v. 60, no. 46, p. 944.

Williams, P. L., Mabey, D. R., Zohdy, A. A. R., Ackermann, Hans, Hoover, D. B., Pierce, K. L., and Oriel, S. S., 1976, Geology and geophysics of the southern Raft River Valley geothermal area, Idaho, USA: United Nations symposium on the development and use of geothermal resources, $2 \mathrm{~d}$, San Francisco, Calif., 1975, Proceedings, v. 2, p. 12731282.
Young, H. W., and Lewis, R. E., 1980, Hydrology and geochemistry of thermal groundwater in southwestern Idaho and north-central Nevada: U.S. Geological Survey Open-File Report 80-2043, 40 p.

Young, H. W., and Mitchell, J. C., 1973, Geothermal investigations in Idaho, part 1, Geochemical and geologic setting of selected thermal waters: Idaho Department of Water Administration Water Information Bulletin 30, 43 p. .

Young, H. W., and Whitehead, R. L., 1975a, Geothermal investigations in Idaho, part 2, An evaluation of thermal water in the Bruneau-Grand View Area, southwestern Idaho: Idaho Department of Water Resouces Water Information, Bulletin 30, $126 \mathrm{p}$.

$-1975 \mathrm{~b}$, Geothermal investigations in Idaho, part 3, An evaluation of the thermal water in the Weiser area, Idaho: Idaho Department of Water Resources Water Information Bulletin 30, 35 p.

Zoback, M. L., and Thompson, G.A., 1978, Basin and Range rifting in northern Nevada; Clues from a mid-Miocene rift and its subsequent offsets: Geology, v. 6, p. 111-116. 